\title{
Musica et medicina
}

\author{
Janka Zoltán dr. \\ Szegedi Tudományegyetem, Általános Orvostudományi Kar, Pszichiátriai Klinika, Szeged
}

\begin{abstract}
Az adott zenei stílusirányzat és előadásmód iránti beállítódástól is függően a muzsika befolyásolhat mentális aktivitásokat, mint érzelem, hangulat, motiváció, pszichomotoros tempó és kogníció. Kísérletes adatok utalnak arra, hogy a zene szomatikus funkciók élettani paramétereit (vérnyomás, szívritmus, perifériás vérkeringés, légzés) képes megváltoztatni. A medicinális és idegtudományi kutatások erőfeszítéseket tesznek, hogy megfejtsék a zene feldolgozásának és előadásának agyi korrelátumait, amiben a modern képalkotó eljárások lényeges előrelépést hoztak. Úgy tünik, hogy nincs egy bizonyos zenei központ, hanem a zene alkotóelemeitől (dallam, ritmus) függően erős hálózati összeköttetéssel több agyterület vesz részt ebben. Kitüntetettek a felső halántéki régiók (elsődleges, másodlagos, harmadlagos hallókéreg), illetve a homlok- és fali lebeny, a limbicus rendszer és a cerebellum részei. Az orvostudomány a fenti szempontokon túl elsősorban a zeneterápia terén kapcsolódik a muzsikához. Kontrollált tanulmányok metaelemzései jelzik, hogy a zene alkalmas lehet stresszállapot, szorongás, illetve depresszió csökkentésére különféle betegségcsoportokban (cardiovascularis, onkológiai, mentális) és orvosi vizsgálatokban (sebészeti, urológiai, szívkatéterezési). Stroke-rehabilitáció terén a motoros, kognitív és pszichoszociális funkciók javulását figyelték meg zenei beavatkozások után. A medicinához tartozik a hangulatzavarok és a zenei kreativitás kapcsolata, amelyre eminens zeneszerzők körében számos példa akad, valamint tudós és praktizáló orvosok kiváló aktív zenélése vagy zeneszerzése.
\end{abstract}

Orv Hetil. 2019; 160(11): 403-418.

Kulcsszavak: zene, agy, medicina, idegtudomány, zeneterápia

\section{Musica et medicina}

Depending on the personal attitude toward a given style and performance, music can influence mental activities such as emotion, mood, motivation, psychomotor tempo and possibly cognition. Experimental data indicate that music can alter physiological parameters of somatic functions (blood pressure, heart rhythm, peripheral blood flow, respiration). However, efforts are taken in medicine and neuroscience to decipher brain physiological and morphological correlates in processing or performing music. Modern imaging techniques brought a significant advance in this respect. It appears that there is no single music center in the brain, but depending on the components (melody, rhythm) of the music, more cerebral areas with strong network connections participate in that. Important regions are the upper temporal area (primary, secondary, tertiary auditory cortex), and parts of the frontal and parietal lobes, limbic system, and cerebellum. Beyond the above aspects, medicine joins to music in the field of music therapy. Meta-analyses of controlled studies show that music can be suitable to decrease stress, anxiety, and depression in various disease groups (cardiovascular, oncological, mental) and in medical examinations (surgical, urological, cardiac catheterization). Improvements were observed in motor, cognitive and psychosocial functions after music interventions in stroke rehabilitation. The links between mood disorders and creativity in music belong to medicine as well, where eminent composers can be mentioned, and also the examples of scholar and practitioner physicians playing or composing music superbly.

Keywords: music, brain, medicine, neuroscience, music therapy

Janka Z. [Musica et medicina]. Orv Hetil. 2019; 160(11): 403-418.

(Beérkezett: 2018. október 11.; elfogadva: 2018. október 27.)

A Szerkesztőség felkérésére készült tanulmány.

\section{Rövidítések}

$\mathrm{ACTH}=$ adrenokortikotrop hormon; Br. = Brodmann; $\mathrm{C}=$ konkordancia; $\mathrm{CB}=$ cerebellum; $\mathrm{CDZ}=$ konkordáns dizigótaráta; $\mathrm{CMZ}=$ konkordáns monozigótaráta; $c f .=$ confer $($ vesd össze $) ; D U S P I=($ dual-specificity phosphatase 1 gene $)$ kettős specificitású foszfatáz-l gén; DZ = dizigóta; EEG = elektroencefalográfia; $\dot{e}=$ értékítélet (tengely); $f=$ feszültség (tengely); $\mathrm{FL}=$ frontalis lebeny; fMR = funkcionális mágneses rezonan- 
cia; $F O S=$ C-fos protoonkogén; FOXP2 = forkhead box P2 gén; g. = gyrus (tekervény); GATA2 = GATA-kötő fehérje-2 gén; GTM = gyrus temporalis medius; GTS = gyrus temporalis superior; $h=$ hangulat (tengely); $\mathrm{HG}=$ Heschl-tekervény; $\mathrm{MEG}=$ magnetoencefalográfia $; \mathrm{MR}=$ mágneses rezonancia; $\mathrm{MZ}=$ monozigóta, egypetéjü $; \mathrm{OL}=$ occipitalis lebeny; $P C D H a$ $=($ protocadherin alpha $)$ protokadherin $-\alpha$ gén $; \mathrm{PET}=($ positron emission tomography) pozitronemissziós tomográfia; $\mathrm{PL}=\mathrm{pa}-$ rietalis lebeny; $P P P 2 R 3 A=$ protein phosphatase 2 regulatory subunit $\mathrm{B} \alpha$ gén; $\mathrm{PT}=$ planum temporale $; \mathrm{PTSD}=($ post trau matic stress disorder) poszttraumás stresszzavar; $\mathrm{rCBF}=$ regionális cerebrális vérátáramlás; $S L C 6 A 4=($ solute carrier $6 \mathrm{~A} 4)$ szerotonintranszporter gén; $S N C A=(\alpha$-synuclein gene $)$ $\alpha$-szinuklein gén; SPECT $=$ (single photon emission computed tomography) egyfoton-emissziós tomográfia; $\mathrm{TP}=$ temporalis pólus; $U G T 8=($ UDP glycosyltransferase 8 gene $)$ UDP-glikoziltranszferáz-8 gén; VNTR = (variable number of tandem repeats) nukleotidszakasz változó számú ismétlődése; ZNF223 = (zinc finger protein 223 gene) cinkujjfehérje-223 gén

A zene ősidők óta az emberi környezet része. A zenének számos közösségteremtő vagy egyéni épülést segítő, a lélek porát lemosó funkciója feltételezhető, bár vannak elméletek, amelyek nem tekintik jelentősnek mindezt (például a nyelv kialakulásához képest). Valóban, sok kimagaslóan értékes személy nem képes a zenét élvezni, kiváltképpen érteni, sőt amusiás egyének is léteznek (ilyen volt Ulysses $S$. Grant amerikai elnök is). A zene akár rekreációra, akár gyógyításra individuális megközelítéssel használható: az emberek sokféle, változatos zenei ízléssel rendelkeznek, sőt egy személyen belül is változhatnak a preferenciák. Minden zene elfogadható, amely feloldódást és örömet jelent; persze az is igaz, hogy olykor éppen nem a megnyugtató, hanem ellenkezóleg, a felkavaróan katartikus vagy akár negatív élmény hozhat az egyén számára lelki fejlődést.

Az ember társas lény, a kisebb-nagyobb csoportokhoz tartozás alapvető igényként jelentkezik. A zenének a társas léttel kapcsolatos funkciói legalább hét aspektusban értelmezhetők (' $7-\mathrm{K}$ '), tételesen a zene (1) kontaktust teremt (amikor az egyének zenélnek, kapcsolatba kerülnek egymással); (2) kognícióra serkent (a zeneszerző szándékainak megértésére való törekvés; autizmusban is megtartott lehet); (3) ko-pathiás hatást vált ki (amely az empathia szétterjedése csoporton belül, az egyének közötti emocionális állapotok homogenizálódása zene hallgatása vagy játszása közben); (4) kommunikációt jelent (amely kisgyermekkorban igen általános, például szülőgyermek viszony; figyelemre méltó, hogy a beszédnek és a zenei képességeknek átfedő agyterületei vannak); (5) koordinációt inspirál a mozgásban (azaz ütemhez való igazodást, ütemtartást; bizonyos emlősök és énekesmadarak is képesek erre); (6) kooperációt, együttmúködést igényel (például a játékosok között a zenei előadás során); (7) kohéziót növel csoporton belül (az egyén társasághoz tartozását erősíti, aminek esztétikai, ízlést formáló hatása is van) $[1,2]$. A zene általánosan elterjedt, a világ minden részén fellelhető a történelemben, és nem ismeretes olyan kultúra, ahol hiányozna. Életünk része, és különlegesen kivételes hatást gyakorolhat az arra fogékonyakra.

Sok híresség megfogalmazott elmés megállapításokat a zene dicső́itésével kapcsolatban, mint Platón ('megragadja, felékesíti és megnemesíti a lelket'), Molinet ('a menny rezonanciája, angyalhang, ördögüző'), Luther ('a teológia rokona, a bánat leghatásosabb orvossága, lélekfegyelmező mester, az Isten szép és dicső ajándéka'), Beethoven ('az egyetlen anyagtalan bejárat egy olyan világba, amely magasabb a tudásnál'), Schiller ('a képzőmúvészet leheljen életet, szellemet sugározzon a költő, de a lelket csak a zene mondja ki'), Heine ('közvetítő a szellem és anyag között'), V. Hugo ('a zene azt fejezi ki, amit szavakba önteni nem lehet, de amiről hallgatni is lehetetlen'), Wagner ('maga a szenvedély, szerelem, vágy') vagy d'Indy ('igazi célja a nevelés, az emberiség szellemének emelése, tanítás és szolgálat'). Többen fölvetettek azonban negatív aspektusokat is, mint Bolyai Farkas ('a zene különböző, mennybe emel, vagy vétekre csábít'), Kinkel ('a zárkózott ember őskinyilatkoztatása'), Tolsztoj ('az emberek egységét megbontó múvészet'), Nietzsche ('gondolat híján énekel, csalás és megcsalatás') vagy $O$. Wilde ('artikulátlan, nem új világot, hanem másik káoszt teremt').

Akárhogyan is van, az adott zenei stílusirányzat és előadásmód iránti beállítódástól is függően a muzsika pozitív vagy negatív módon befolyásolhat mentális tevékenységeket, mint érzéseket, érzelmeket, hangulatot, motivációt, pszichomotoros tempót és feltehetően gondolkodási-megismerési múködéseket is. Ezen pszichés válaszok humán testi funkciók fizikális megváltozását is kiválthatják továbbá. Azok a mechanizmusok viszont, amelyek ezen mentális és fizikális válaszreakciók mögött rejlenek, pontosan nem ismertek. Az ideg- és orvostudomány ugyanakkor komoly erófeszítéseket tesz, hogy megfejtse a zene percepciója, felfogása, feldolgozása, illetve előadása vagy létrehozása agyélettani és agyszerkezeti korrelátumait. Zene hallgatása vagy zene játszása közben az érzékelési, érzelmi, gondolkodási, mozgási és vegetatív múködések tanulmányozása az emberi agy komplex viselkedésszervező szerepének jobb megismerését célzó medicinális és idegtudományi megközelítések fontos kutatási területét képezi.

\section{Evolúciós kitekintés}

Archeológiai leletek mutatják a zene használatát ősidők óta. Felmerül a kérdés, hogy a zene melléktermék-e a filogenezisben, vagy lehetett valami funkciója? Több mint 50000 éves, francia és szlovéniai ásatási leletek csontból (medve, őz, keselyü) készült furulyaféléket találtak [3, 4]. Újabb archeológiai zeneszerszámleletek származnak 
Délnyugat-Németországból (Hohle Fels és Vogelherd, Ulm környéke). Az ásatások egy fakókeselyú (Gyps fulvus) radiusából készült majdnem teljes furulyát és három kisebb, mamutagyarból készült furulyadarabot találtak a kezdeti felső paleolit időszakból. A több mint 35000 éves leletek zenei tradícióra utalnak azzal az eredményekre alapozott spekulációval, hogy a Neander-völgyi emberhez képest nagyobb csoporthálózatok léteztek jobb territoriális eloszlással és demográfiai expanzióval. A táncnak feltehetően különleges szerep jutott. Bilzingsleben (Németország) archeológiai ásatási területein kikövezett régiókat találtak (kövek, felszínbe préselt csontok és fogak, valamint elefántagyarral jelölések), amelyek időleges letelepedés jelei. A tüzhasználatra szenesedések utalnak, tûzhelyek nyomai. Ezenkívül 8-9 m átmérôjú kör alakú tiszta területeket és e körül csoportosan elhelyezett szerszámokat is sikerült lokalizálni, amelyek feltehetően rituális 'performancia'események, tánc számára készülhettek.

Bizonyos felfogások szerint a zene nem más, mint melléktermék, appendix, filogenetikus maradék, üres boltív ('spandrel'), akusztikus 'cheesecake', míg Darwin elő(proto)nyelvnek tartotta, ső́t (ami talán nem meglepő) a zenének az ellenkező nemet elbűvölő varázslata révén a szexuális párválasztásban tulajdonított szerepet (emberben azonban erre nincs bizonyíték). Panaszkodott, hogy nincs muzikalitása, de nejének (Emma) kiváló volt, naponta zongorázott otthon. Gyermekei tehetségét is figyelve, ezen képesség örökletességében hitt, és úgy érvelt, hogy az evolúcióban ezen képesség a szexuális vonzerőt mint kommunikációs formát képviselte a nyelv előtt.

Tagadhatatlan, hogy a zene az emberiség történetében a munkában és rekreációban a társas szerveződést, a kohéziót, a csoportharmóniát, a szolidaritást és a közösségteremtést szolgálta. Az édesanya és a csecsemő/gyermek közötti zenei kommunikáció, különösen dal formájában (dúdolás, nyugtatás, figyelemfelkeltés, altatódal, bölcsődal, zenés beszéd: 'motherese'), minden kultúrában ismeretes [4]. A (hangszeres és vokális) zene jellegzetességeit a beszélt nyelvvel és a vokalizációval (kiáltás, hanghatás) összevetve számos aspektusból vizsgálták. A zenénél meglévő bonyolultság, szabályok rendszere, kulturális átörökítés és magassági transzponálhatóság a beszélt nyelvnél is észlelhető (vokalizációnál egyik sem), míg az elkülönült hangmagasságok, ütem, taktus, előadási környezet, az ismétlésben élvezhetôség és emocionális expresszivitás már nem annyira (nyilván a vokalizációnál sem, kivéve az emocionalitást) [2]. A számi etnikai népcsoportok főként Észak-Skandináviában (Norvégia, Svédország, Finnország) és az oroszországi Kola-félszigeten élnek. Hagyományos 'éneklő' stílusuk a yoik, amely vokális jellegú, esetleg dobkísérettel, tulajdonképpen szótagok rövid ismétlődő ciklusai nyelvi értelem nélkül.
Tehát nem szavakkal fejezik ki mondanivalójukat, amely igencsak személyes: mindennapi életükről, állatokról, természeti jelenségekről, személyekről szól.

Csak néhány állatféle 'muzikális'. A púpos bálnák akár 7 oktáv terjedelemben hallatnak hangot a tengerben; a hangközök, a ritmus, a zenei témák akár 'emberinek' is tekinthetók az énekek organikus építkezése, témabemutatás, -kidolgozás, az eredeti téma enyhén módosított visszatérése, rímszerú refrének (emlékezés elősegítése) miatt. Az inuit, tlingit és egyéb tengerjáró törzsek évezredek óta hallhatták csónakjaikban az óceánon a bálnák énekét. Nőstény afrikai elefántok körülbelül $21 \mathrm{~Hz}$ frekvenciás (infratartomány), 4-5 mp-es kommunikációi (kapcsolati hívások) néhány kilométerre terjednek. Nem túl régen regisztrálták, de a tuszi és hutu törzsek (Középkelet-Afrika) régen ismerték, dalaikba és történeteikbe évszázadok óta beépítették [3].

$\mathrm{Az}$ énekesmadarak sok érdekességet mutatnak. A szurdoki ökörszem (Catherpes mexicanus) például kromatikus skálán (oktáv = 12 félhang) énekel, trillája hasonlít például Chopin: c-moll ('Forradalmi') etűdjének (op. 10., No. 12.) elejéhez. Az erdei fülemülerigó (Hylocichla mustelina) az emberi zenei skálához pontosan hasonló hangmagasságokat énekel. A pettyes fülemülerigó (Catharus guttatus) pentaton ( 5 hang az oktávból, magyar népzene és a kínai zene jellegzetessége) skálát használ énekében. A kaliforniai mocsári ökörszem (Cistothorus palustris) 120 különféle témát képes énekelni meghatározott sorrendben. A szigeti gezerigó (Mimus graysoni) rövid zenei témák hosszú sorozatát énekli, a sokszavú poszáta (énekes gezerigó) (Mimus polyglottos; 'mockingbird') a közvetlen szomszéd minden zenei témájára azonossal válaszol, tehát gúnyolódóan utánozza. A rubinfejü királyka (Regulus calendula) énekének első és második része között gyakran egy oktáv hangköz különbség észlelhető. Bizonyos énekesmadarak (Anna-kolibri - Calypte anna, koronás verébsármány - Zonotrichia lewcophrys, erdei pinty - Fringilla coelebs) horizontális zenei tradíciót mutatnak, azaz a korosztálytársak egymástól tanulnak, míg mások vertikálisat, azaz utódokat tanítanak (süvöltő - Pyrrbula pyrrbula, zebrapinty - Taeniopygia castanotis). A hím pálmakakadu (Probosciger aterrimus) párzási rituáléjában faágból dobverő́t készít, és üreges fatörzsön dobol.

Általános emberi jellegzetesség, hogy zenei ütemre ritmikus szinkronizációs mozgást produkálunk (fejbólintgatás, kézmozgatás, lábdobogás vagy tánc). A vokális tanulás és ritmikus szinkronizáció hipotézisének értelmében egy zenei ütem felvétele (szinkronizáció, 'entrainment') komplex vokális tanuláshoz szükséges idegi kapcsolódási körök feltétele (szoros összeköttetés a hallási és a motoros pályarendszerek és mezők között). A hipotézis sejteti, hogy a vokálisan tanuló állatok (éne- 
kesmadarak, bálnák, fókák) képesek zeneiütem-szinkronizációra (de a nem emberszabású majmok nem). Egy kakadufajta (nagy sárgabóbitás kakadu - Cacatua galerita eleonora, 'sulphur-crested') kísérletesen igazolt ütemszinkronizációt mutatott ('head-bob'). A zenei részlet tempóját széles tartományban változtatva, az állat a saját ritmikus mozgási tempóját volt képes ehhez igazítani [5]. Öt hónapos csimpánzok a konszonáns zenét részesítették elönyben. Az újvilági majmok (oroszlánmajmocska, selyemmajom) (a) a lassúbb tempójú zenét preferálták, (b) ha a csend és a lassú zene között választhattak, a csendet választották, (c) a disszonáns-konszonáns zenei különbséget nem érzékelték, (d) a fajra specifikus táplálkozással kapcsolatos hangot ('chirp') preferálták a fajspecifikus, rémületet jelző sikítással ('scream') szemben, (e) a halkabb hanghatást preferálták a hangoshoz képest, és (f) karcolásszerű hang (köröm asztallapon, 'screech') és hasonló amplitúdójú semleges zaj ('white noise') között nem tettek különbséget [6].

\section{A zenefeldolgozás agyi korrelátumai}

Tudományos adatok jelzik, hogy emberben a zenei érzet agyi korrelátumai modern in vivo képalkotó eljárásokkal elemezhetők, és szubjektív komponensekkel is összevethetők. A kvantitatív pszichológiai mérőeszközökkel kombinált strukturális és funkcionális idegrendszeri kép- alkotó eljárásoknak - mint mágneses rezonancia (MR), funkcionális MR (fMR), pozitronemissziós tomográfia (PET), egyfoton-emissziós komputertomográfia (SPECT), elektroencefalográfia (EEG), magnetoencefalográfia (MEG) - köszönhetően az agynak a zenében betöltött szerepéról számos adat áll rendelkezésre [7]. Úgy tûnik, hogy nincs egy bizonyos zenei központ, hanem inkább több nagy- és kisagyi terület vesz részt a zenei feldolgozásban. Ezen agyrégiók tipikusan olyan mezők, amelyek más érzékelési, megismerési, gondolkodási, érzelmi és mozgatómúködések kapcsán is funkcionális aktivitást mutatnak. A zenei feldolgozás szempontjából azonban vannak kitüntetettebb agyterületek, mint a felsô temporalis régiók, illetve a homlok- és fali lebeny, a limbicus rendszer és a cerebellum részei.

A gyrus (g.) temporalis superiorban elhelyezkedő elsődleges hallási kéregmező (Brodmann [Br.] 41-42-es area) a zene első cerebrális feldolgozási állomása ( 1 . ábra). A zene alkotóelemeitől függően, kétirányú hálózati információáramlás segítségével, különböző agyterületek vesznek részt a további feldolgozásban, mint a planum temporale (hangköz, dallam [melódia], hangszín, ritmus, térbeli lokalizáció), az elülső és oldalsó Heschltekervény (hangköz, dallam, hangszín, ritmus, felismerés), a kisagy (ritmus), a fali lebeny (térbeli lokalizáció, ritmus, memória), a g. temporalis medius és a halántéklebenycsúcs (felismerés), a homloklebeny (harmónia/

\title{
Elsődleges h.k. $\square$ Másodlagos h.k. $\square$ Harmadlagos h.k.
}

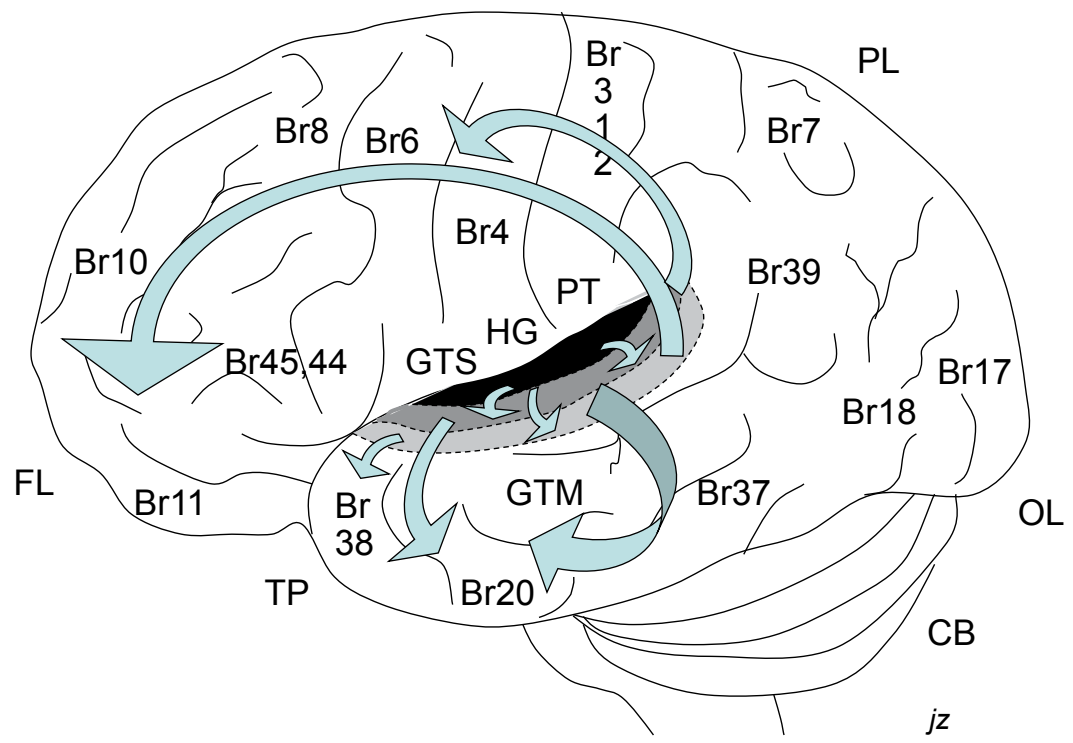

1. ábra

\begin{abstract}
Az elsődleges hallókéreg (Brodmann 41-42-es area) a thalamusból (az ábrán nem látható) érkező input alapján azonosítja a zene alapvető tulajdonságait (hangmagasság = frekvencia; ritmus, hangerő). A másodlagos hallókéreg ezen információkra építve feldolgozza a zene harmóniai, melódiai és ritmikai mintázatát. A harmadlagos hallókéreg mindent integrál az egyén számára mint általános zenei élmény ( $c f$. szöveg). A zene hangszeres és vokális előadásakor a mozgatókéreggel és a motoros beszédközponttal (Brodmann 4-es, 45-44-es areák), kottaolvasáskor az occipitalis kéreggel természetszerúen állandó az információcsere. A hallókéregből a pályák (axonkötegek) az agy különféle területeibe, többek között a frontalis és a parietalis lebenybe, a temporalis pólusba, a cerebellumba, a cingulumba, az insulába, a hippocampusba, a hypothalamusba, zenétől függően a nucleus accumbensbe (örömközpont), az amygdalába (félelemközpont) sugároznak (a mélyebb struktúrák az ábrán nem látszanak)

$\mathrm{Br}=$ Brodmann; $\mathrm{CB}=$ cerebellum; $\mathrm{FL}=$ frontalis lebeny; $\mathrm{GTM}=$ gyrus temporalis medius; $\mathrm{GTS}$ = gyrus temporalis superior; $\mathrm{HG}=\mathrm{Heschl-tekervény;}$
\end{abstract} h.k. = hallókéreg; $\mathrm{OL}=$ occipitalis lebeny; $\mathrm{PL}=$ parietalis lebeny; $\mathrm{PT}=$ planum temporale (részint mélyebben); $\mathrm{TP}=$ temporalis pólus 
hangnem, munkamemória, viselkedésválasz, mozgáskimenet, előadás/játék), az insula és a limbicus körök (érzelem, felismerés).

A primer hallókéreg (g. temporalis superior) a thalamusból érkező információk alapján azonosítja a zene alapvető tulajdonságait. A szekunder hallókéreg erre építve feldolgozza a zene dallambeli és ritmikai mintázatát. A tercier hallókéreg mindent integrál az egyén számára mint általános zenei élmény (hangköz, dallam, akkord, harmónia, hangnem, skálák, hangszín, énekszöveg, oktáv és transzpozíciós ekvivalencia, ritmus, ütem, szerkezet). A hallókéregből a pályák az agy különféle területeihez eljutnak (temporalis pólus, motoros, premotoros, praefrontalis kéreg, g. cinguli, fali és nyakszirtlebenyek, insula, nucleus accumbens, amygdala, hippocampus, hypothalamus, kisagy) (1. ábra). A zenei feldolgozás idegtudományi megközelítései ígéretes lehetőséget nyújtanak annak jobb megértésére, hogy a humán agy miként érzékeli és hozza létre a zenét, valamint hogy miként reagál rá érzelmi/gondolkodási/viselkedési módokon, csökkentve talán, de remélhetően nem megfosztva a zenét jótékonyan misztikus és rejtélyes karakterétől. A medicina a zenéhez azzal a sajátos (és sokszor sajnálatos) aspektussal is tud csatlakozni, hogy különféle cerebrális betegségekben az agykárosodás pontos helyét és mértékét korreláltatja az adott személy esetleges zenei deficitjeihez (hangmagasság-távolság, -mintázat; hangszín; ritmus, tempó; zenei memória ismert és új anyag tekintetében; érzelmi válasz és értékelés) [8].

Congenitalis amusiában, a zenei képesség veleszületett hiányában (teljes botfülüség) képalkotó módszerekkel (MR) a jobb oldali g. frontalis pars opercularis területén fehérállomány-deficitet találtak, amelynek következménye a primer hallókéreggel való kapcsolódás elégtelen jellege. A vizsgálatokat parallel két központban is elvégezték, Montrealban (amusia: $\mathrm{n}=13$, kontroll: $\mathrm{n}=22$ ) és Newcastle-ban (amusia: $\mathrm{n}=8$, kontroll: $\mathrm{n}=7$ ), ahol a teszteredmények ('Montreal Battery of Evaluation of Amusia') hasonló értékeket mutattak az amusiás egyénekben (a 2 helyszín összegzéseként a melódia terén helyes válasz az 51-72\%-os tartományban, a ritmus terén az 53-96\%-os tartományban), szemben a kontrollszemélyek értékeivel (melódia, helyes válasz: 80$100 \%$, ritmus: $77-100 \%)$. Az amusiateszt hangmagasságtorzítás-felismerési és zeneimemória-értékei mindkét helyszínen pozitív korrelációt mutattak a jobb oldali g. frontalis inferior fehérállomány koncentrációjával [9].

A hangmagassággal kapcsolatos a dallam (hangmagasság-mintázat az idő függvényében), az akkord (szimultán hangmagasságok) és a harmónia (több melódia szimultán megjelenése). A g. temporalis superior elülső és hátulsó részében agyi aktivációk figyelhetők meg dallam hatására, jobb oldali túlsúllyal. A jelzett területek károso- dásai, amennyiben jobb oldaliak, inkább vezetnek a dallam felismerésének zavarához, a bal oldalhoz képest. A dallam és ritmus agyi feldolgozásának vizualizálása céljából számos vizsgálatot végeztek. Alternáló, oktáv különbségű tiszta hangok (ahol vagy a magassági, vagy az időbeli jellemzők változtak) alkalmazásával regionális cerebrális vérátáramlási (rCBF) PET-különbségeket észleltek, és ebben oldalkülönbség is mutatkozott: bal oldalon nagyobb aktivitás a Heschl-gyrusban az időtényezők változtatására, míg jobb oldalon az elülső felső halántéki régióban (g. temporalis superior) a hangmagasság hatására [10]. Az egyik (idő) változtatás a ritmus, a másik (hangmagasság) a dallam alapja.

Olyan kottasorozatok szándékos előállításával, amelyeknél a dallam és a ritmus bonyolultsága elvált (csak dallamvariálás ritmusváltoztatás nélkül, illetve fordítva, vagy a kettő kombinációja $2 \times 2$-es kísérleti elrendezésben), a kottáról történő zongoralejátszás alatt agyi fMRvizsgálatokat végeztek. A dallamfeldolgozás kapcsán nagyobb neuralis aktivitás mutatkozott a medialis occipitalis lebenyben (sulcus calcarinus), a jobb és bal oldali g. temporalis superiorban és a lateralis cerebellumban. A ritmus agyi feldolgozása alatt a nagyobb aktivitás a bal g. frontalis inferior, a g. supramarginalis, az oldalsó occipitotemporalis tekervény, a jobb oldali g. fusiformis, illetve a medialis és lateralis cerebellum területein jelentkezett.

Funkcionális MR-vizsgálatokkal bizonyos agyterületeken (amygdala, retrosplenialis cortex, agytörzs, cerebellum) nagyobb aktivációkat mértek moll akkordok passzív hallgatására, mint dúr akkordokéra. Hasonló volt a helyzet disszonáns akkordok hallgatásakor. A dúr, moll és disszonáns akkordok emocionális értékelése zenész ( $\mathrm{n}=$ $11)$ és nem zenész $(\mathrm{n}=10)$ vizsgálati személyekben történt. Bár a moll akkordot a zenészek szomorúbbnak, a disszonáns akkordot kellemetlenebbnek értékelték, mint a nem zenészek, a két csoport alapvetően nem különbözött egymástól [11]. Nem zenész és abszolút hallású zenész foglalkozású egyének cerebrumát nagy felbontású MR-készülékkel vizsgálva és kétoldali planum temporale felszín rekonstrukciókat végezve érdekes és szignifikáns különbséget találtak a jobb oldali planum temporale esetében; az abszolút hallású zenészeké volt kisebb ('pruning' hatás?) [10]. Szabályos ritmus passzív érzékelése zenész és nem zenész egyénekben fMR-vizsgálatban azt mutatta, hogy a zenészekben az aktivitás bal oldali túlsúlyú és a Sylvius-árok (sulcus lateralis cerebri) környékén jellegzetes, míg a nem zenészekben az aktivitás enyhe jobb oldali túlsúlya látszódott [10]. Az ütem és a ritmus változtatásainak képalkotó eljárásokkal (fMR, EEG 'mapping') való kombinációja nagy átfedéseket és finom különbségeket mutatott ki a zene e két időtényezője között. Jazz/rock zenészek csoportjában ( $\mathrm{n}=17$, Århus, Dánia) a ritmusérzék növekedésével a Br. 4-es area (primer mozgatókéreg) és a Br. 20-as area (g. temporalis inferior) bizonyos részein voxelalapú MR-morfometriával szürkeállománydenzitás-emelkedést találtak. 
Egészséges önkéntesekben $(\mathrm{n}=26)$ semleges és negatív, nem ismert zenei részek nyitott és csukott szemmel történő meghallgatásának kísérleti elrendezése befolyásolta a zenei élményt. Az adott értékelések szignifikáns különbséget a nyitott és a csukott szem között csak a negatív zene esetében mutattak; az fMR-mérések szemcsukásra az amygdalában és az elülső hippocampuskomplexben jeleztek aktivációs különbségeket, de csak a negatív zene kapcsán. Az adatok arra engednek következtetni, hogy csukott szemnél az amygdalának (félelemközpont) fontos szerepe van az emocionális zenei élmény közvetítésében [12].

A zene örömet, bizsergést ('chills') és libabőrérzést kiváltó karakterének képalkotó eljárásokkal (például PETrCBF) történő vizsgálata során pozitív korrelációt találtak bizonyos agyi régiók (ventralis striatum, dorsalis középagy) és az említett érzések intenzitása között, míg negatívat más agyterületekkel (hippocampus, amygdala, ventralis medialis praefrontalis cortex). A zenei darabokat maguk a vizsgálati személyek választották e célra. Az intenzív zenei kedvelés tehát a jutalmazási és örömemóciók agyi régióinak aktivitásnövekedésével korrelált. Az öröm és jutalmazás klasszikus neurotranszmittere a dopamin, amely a fentebb említett ventralis striatum (nucleus accumbens) területén nagyobb koncentrációban található. PET-módszerrel megfelelő dopamin D2-receptor-gátló liganddal ([$\left.{ }^{11} \mathrm{C}\right]$ rakloprid) indirekt módon megítélhető az endogén dopamin különféle jutalmazó ingerekre történő felszabadulása: a radioligand $\left[{ }^{11} \mathrm{C}\right]$ rakloprid receptorkötési potenciáljának csökkenése fokozott endogéndopamin-elérhetőséget jelez. Ezen metodikával azt találták, hogy élvezetet nyújtó zene hallgatása (a semleges természetû zenéhez képest) a tetőpontban (bizsergés, lúdbőr) szignifikáns kötésipotenciálcsökkenést (= dopaminfelszabadulást) eredményezett a vizsgálati személyek bizonyos agyi struktúráiban (nucleus accumbens, nucleus caudatus, putamen). A bizsergésérzés intenzitása és a jelzett élvezet foka korrelált a ventralis striatum (nucleus accumbens) PET-módszerrel kimutatott dopaminfelszabadulási mértékével [13].

\section{Zene és agyi plaszticitás}

A zene a cerebrális plaszticitásra is kihatással van. A zene hatására bekövetkező plasztikus agy szerkezeti változásaira utal, hogy MR képalkotó eljárásokkal zenészekben a primer motoros kéreg, az elülső corpus callosum és a planum temporale nagyobb területeit találták [14]. Az aktív zenélés agyszerkezeti befolyását jelzi, hogy férfi zenészekben az élet során folytatott gyakorlás intenzitása (óra/nap) pozitív korrelációt mutatott a relatív kisagyi térfogattal. Professzionális $(n=20)$ és amatőr férfi zenészekben $(n=20)$, valamint nem zenész férfiakban a szürkeállomány térfogatának különbségét találták a bal oldali g. praecentralis és Heschl-tekervény, valamint a jobb oldali felső parietalis cortex területén; a legmagasabb értéket mindenhol a professzionális zenészek adták, az amatőrök pedig a köztit. MR corticalis vastagság morfometriával nagyobb értéket találtak zenészekben a kétoldali dorsolateralis frontalis és felső temporalis régiókban. $\mathrm{Az}$ abszolút hallás képességével rendelkezők pedig az azzal nem rendelkezókhöz képest mutattak különbséget a g. frontalis superior hátsó területén (rostralis Br. 6-os - caudalis Br. 8-as areák). A szenzorimotoros integráció és a zenei gyakorlás érdekes összefüggését jelzik az akusztikusesemény-függő potenciál EEG 'mapping' adatai [14]. A két feladat rövid zongoramuzsika meghallgatása és néma zongorabillentyűzeten történő játék volt. A két feladat elektrofiziológiai térképe zeneileg teljesen gyakorlatlan személyekben $78 \%$-os egyezést mutatott. 20 perces vagy 20 napos gyakorlás után a hasonlóság a két feladat során kapott térkép között egyre emelkedett (85\%-ra, illetve 95\%-ra), míg professzionális zenészekben (körülbelül 20 éves gyakorlottság) az egyezés közel teljes volt $(98 \%)$.

A focalis dystonia neurológiai zavar, zenészekben is előfordul (zenészgörcs), sőt viszonylag gyakran a professzionális előadómúvészek körülbelül 1\%-ában fellép, és zenei karrierjüket erősen veszélyezteti $(R$. Schumann zeneszerzőt is érintette, vagy L. Fleisher és G. Graffman zongoramúvészek esete). Zongoristáknál és hegedűsöknél az ujjak, a kéz, a kar, míg réz- és fafúvósoknál az ajak, a nyelv, az arc- és nyakizmok mozgását érinti egyfajta izomhypertonia. A hangszer típusától függően változékony módon a gyors futamok kontrolljának elvesztése, ügyetlenség, az ujjak leragadása, flexiója vagy extensiója, a száj körüli izmok görcse jellemzi. Az érintettek azt hiszik, hogy mozdulataik pontosságcsökkenésének eredete technikai probléma vagy a gyakorlás hiánya. Emiatt még többet gyakorolnak, és az állapot gyakran még rosszabb lesz. Kézujj focalis dystoniában képalkotó eljárással és szenzoros stimulációval a hüvelykujj és a kisujj ellenoldali agyi szomatoszenzoros reprezentációjában ('homunculus') a távolságot az ép oldalnak megfelelően 2,5 cm-nek mérték (Dl-D5), míg ez jóval kisebb volt a focalis dystoniának megfelelő oldalon; az ujjak kérgi vetületei nem váltak el, mintegy összecsúsztak, különösen a középső, a gyưrűs- és a kisujjak (D3-D5) esetében [14].

A zenei gyakorlás agyfejlōdésve kifejtett hatását vizsgálták 6 éves gyermekekben. Alap-MR-t végeztek, majd 15 gyermeknél hangszeres képzés következett, 16 gyermeknél pedig nem (kontroll). 15 hónap múlva ismételt MR készült, és a zenei csoportban agyszerkezeti változásokat (növekedést) figyeltek meg a primer motoros és hallási mezőben, illetve a corpus callosumban a kontrollhoz képest, amelyek korreláltak a zeneileg releváns motoros és hallási képességek javulásával [9]. A zenei képzés kihathat egyéb funkciók fejlődésére is. Finnországban óvodás (5-6 éves) gyermekek $(n=66)$ heti $(30 \times /$ év $)$ zenei kép- 
zése ('playschool') 18 hónapon át követve folyamatosan és egyenletesen növelte a nyelvi készségüket a (játékos zenei képzésben nem részesülő) kontrollcsoporthoz képest mind a fonémafeldolgozás, mind a szókincs terén. A táncleckékkel összehasonlítva ugyanakkor önmagukban csak a táncleckéknek nem tudtak ilyen értelmü hatást tulajdonítani [15].

Los Angeles körzetében viszonylag szegényebb társadalmi rétegből származó, latin etnikumú, 6-7 éves iskolás gyermekek 3 csoportját random módon alakították ki, és az egyiket iskola utáni zenei képzésben $(n=21$, heti 6-7 óra zenei képzés a venezuelai 'El Sistema' program alapján), a másikat testnevelésben $(n=23$, futball vagy úszás, hetente többször, edzőkkel) részesítették, míg a harmadik (kontroll)csoport $(\mathrm{n}=24)$ semmilyen extra képzést nem kapott az iskolain kívül. A vizsgálat kezdetén agyi MR, 'diffúziós tensor imaging' felvételek készültek, majd 2 év múlva ismét. Azt találták, hogy a sport- vagy a kontrollcsoporthoz képest a zenei képzést kapó csoportban a frakciós anizotrópia szignifikánsan magasabb volt a corpus callosum g. frontalis superior/ supplementer motoros area, a g. praecentralis és a g. postcentralis területeket összekötő rostok szegmensében. A zenei képzésben részesültek a Stroop gátlási kognitív tesztben jobb eredményt értek el, különösen az inkongruens próbákban, amelyeket nagyobb fMR-aktivitás kísért a kétoldali g. frontalis inferior, a supplementer motoros area, a g. praecentralis, az elülső cingulum és az insula területén. Az akusztikus ügyességi feladatokban (például hangdiszkrimináció) is értelemszerúen jobban teljesítettek a zenei képzésben részesült gyermekek [16].

\section{A zenei élmény vizsgálata}

A jó közérzet, a jóllét, a boldogság, a testi-lelki egészség, az eudaimonia forrásai szellemi, testi, társadalmi/gazdasági természetűek lehetnek, amelyek közé a zene és az éneklés is beletartozik, elsősorban örömérzés- és élvezetkiváltás, szorongáscsökkentés, hangulat- és életminőségjavítás révén. Mindennek népegészségügyi kihatása is lehet. A mentális és anyagi dolgok kedvelésének, élvezetének ciklikus jellege van. A ciklikus jelleg érvényes a zene vagy egyéb szellemi-kulturális esemény/aktivitás kiváltotta örömérzésre is. Az appetitív fázis a remélés, a várakozás, az akarás, a consummatiós a kedvelés, a valós élmény, a fogyasztás, az élvezet, a satietas a jóllakottság, a telítődés, a megelégedettségérzés, amely tanulásilag rögzül [17].

Az örömérzés elérése bizonyos agyrégiók (nucleus accumbens, ventralis tegmentalis area) és kémiai rendszerek (például dopamin) optimális múködésének is függvénye, amit a modern képalkotó vizsgálatok igazolni látszanak ( $c f$. A zenefeldolgozás agyi korrelátumai címü fejezet). A zene esztétikai megítélésében is döntő bizonyos agyterületek szerepe, fóként kapcsolódási mintázata (neuroesztétika mint új diszciplina szerveződött). fMR- rel vizsgálva, az agy alapállapotú hálózati múködésekor ('default-mode network') zene hallgatására a praecuneus terület aktív, amely a zene esztétikai elutasításakor ('dislike') nem kapcsolódik a parietalis és medialis praefrontalis kéreghez, kedvelt vagy kedvenc zene esetében viszont igen. A zenehallgatás során eudaimoniát nyújtó cerebrális jutalmazási areák (ventralis striatum, pallidum, thalamus, insula, amygdala, olfactorius cortex) és a zenei percepciót közvetlenül végző hallókéreg (g. temporalis superior és medius, operculum, Heschl-tekervény) hálózati összeköttetésben állnak egymással [18].

A zenei élményközvetítés módosulásának pszichológiai mechanizmusai közé tartozik az értékelő kondicionálás, amikor a zenéhez korábban bizonyos kontextusban (például baráti társaság) kapcsolt pozitív vagy negatív ingerek az élmény valódi kiváltói. A zene által felidézett vizuális képzet (például tájkép imaginálása) is módosító tényező, csakúgy, mint az epizodikus memória, amikor a személy életéből idéz fel emlékébe kellemes vagy kellemetlen eseményt a zene. A hallgatóban bizonyos zenei elvárás is lehet az adott múvel kapcsolatban. Amennyiben ez nem teljesül vagy ellenkezője lesz, késik vagy akár igazolást nyer, érzelmet válthat ki. A ritmusra mozduláskor a zene eróteljes üteme befolyásolhatja a szervezet bizonyos ritmusait (légzés, pulzus), ami visszahathat az érzelmekre. Az sem elhanyagolható, hogy agytörzsi reflexek aktiválódhatnak a zene bizonyos karakterére (váratlanság, nagy hangerő, dinamikus változások, disszonancia); ezek gyorsak, automatikusak és érzéseket váltanak ki (izgalmi állapot, meglepetés). Számos zenei példa említhetó, ilyen például J. Haydn No. 92. G-dúr 'Üstdob' szimfóniájának II. tételében a halk előkészítés után váratlanul, meglepetésszerúen bevágó nagy hangerő; angol neve emiatt is 'Surprise' (meglepetés).

A szegedi munkacsoport különféle karakterü zenei részleteket (oldott, nyugtató, lassú: J. S. Bach: d-moll hegedú-oboa verseny, Adagio tétel; dinamikus, erőszakos, agresszív: $R$. Wagner: A walkürök lovaglása - A walkür, III. felvonás; vidám, boldog, gyors: G. F. Händel: B-dúr concerto grosso, op. 6., Hornpipe tétel) hallgattatott meg kontrollszemélyekkel $(\mathrm{n}=80$, pszichopatológiamentes neurológiai betegek, orvostanhallgatók, zenemúvészeti hallgatók), valamint különféle mentális és neurológiai zavart (depresszió, mánia, anxietas, szkizofrénia, drogaddikció, epilepszia) mutató betegekkel $(\mathrm{n}=107)$ [19]. Ezután 7 fokozatú, negatív és pozitív tartományt tartalmazó $(-3--2--1-0-+1-+2-+3)$ szemantikai differenciálskála (melléknévpárok) segítségével feszültség- (f), hangulat- (b) és értékítélet- (é) dimenziók (tengelyek) mentén vizsgálták a zenei élmény jellegzetességeit: az f-tengelyhez tartozó melléknévpárok a következők voltak: feszült-oldott, erőszakos-békés, kemény-lágy, felzaklató-megnyugtató; a $b$-tengely melléknévpárjai: boldog-szomorú, vidám-komoly, lendületesvisszafogott, élénk-egyhangú; míg az é-tengelyéi: gazdag-szegényes, vonzó-visszataszító, mélyreható-felszínes, világos-zavaros (2. ábra). 


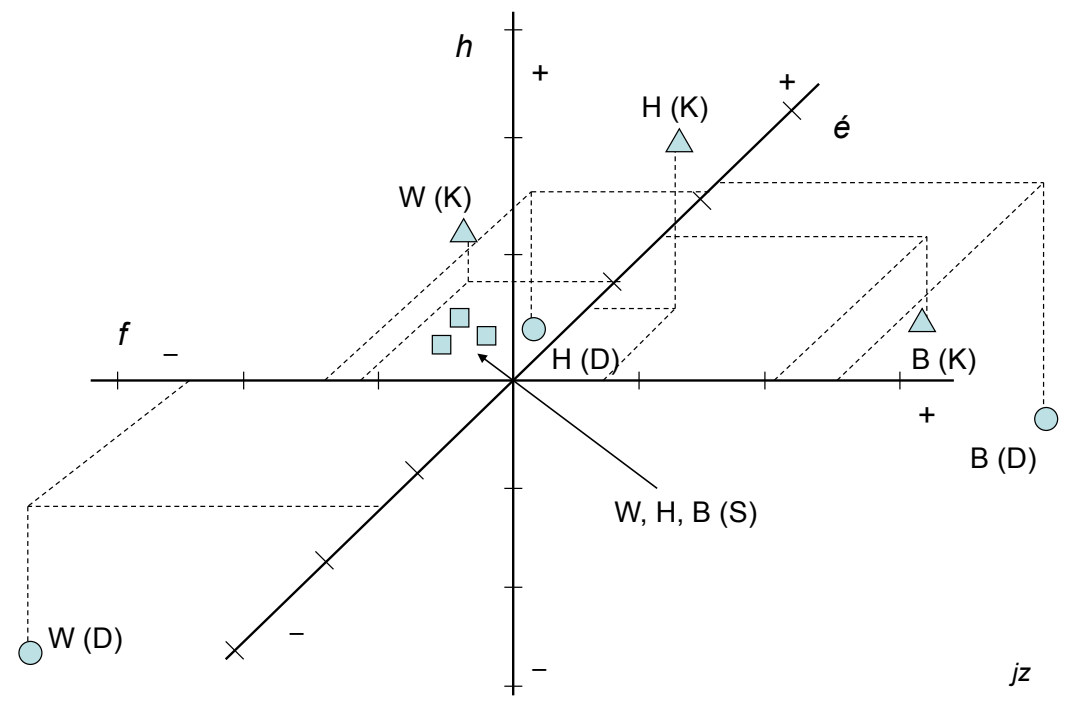

\begin{abstract}
Zenei élmény pszichometriai megítélése szemantikai differenciálskálával. A kontrollcsoport átlagainak (K, háromszögjelek) és egy depressziós (D, kör), valamint egy residualis szkizofréniás ( $S$, négyzet) beteg válaszainak ábrázolása 3 dimenziós térben a feszültség $(f)$-, a hangulat (b)- és az értékítélet (é)-tengely mentén. A meghallgatott 3 eltérő karakterű zenei részlet: J. S. Bach: d-moll hegedú-oboa verseny, Adagio tétel (az ábrán rövidítve: B); R. Wagner: A walkürök lovaglása - A walkür, III. felvonás (rövidítés: W); G. F. Händel: B-dúr concerto grosso, op. 6., Hornpipe tétel (rövidítés: $\mathrm{H})$. Az $f$-, a $b$ - és az é-tengelyhez tartozó 7 fokozatú, negatív és pozitív tartományt tartalmazó $(-3--2--1-0-+1-+2-+3)$ szemantikai differenciálskála melléknévi ellentétpárokból álló vizuális analóg skála, amelyen a vizsgálati személyek a zene meghallgatása után élményeiket bejelölték. Az $f$-tengelyhez tartozó melléknévpárok: feszült-oldott, erőszakos-békés, kemény-lágy, felzaklató-megnyugtató; a $b$-tengely melléknévpárjai: boldogszomorú, vidám-komoly, lendületes-visszafogott, élénk-egyhangú; míg az é-tengelyéi: gazdag-szegényes, vonzó-visszataszító, mélyreható-felszínes, világos-zavaros. Az ábrán a 3 dimenziós térben kivehető a kontrollcsoporthoz (K, háromszög) képest a depressziós személy (D, kör) eltérő zenei élménye, valamint az is, hogy a residualis szkizofréniás beteg ( $\mathrm{S}$, négyzet) nem volt képes kellően elkülöníteni a három eltérő karakterű zenét (W, H, B), ami az emocionális elsivárosodás jelének tekinthető
\end{abstract}

A pszichometriai eredmények azt mutatták, hogy a mániás csoportban a dinamikus és erőteljes karakterü Wagner-zene a hangulat- és az értékítélet-tengelyen pozitívabb élményt adott (csoportátlagértékben kifejezve), míg depresszióban a lassú, szomorkásan nyugtató Bachzenei részletet oldottabbnak (a feszültségtengelyen negatívabbnak) találták; a többi betegcsoport nem különbözött szignifikánsan egymástól és a kontrollcsoporttól. Ugyanakkor, személyre bontottan, ki lehetett szúrni néhány pszichiátriai beteget, akinél a három jellegzetesen különböző zene nem vált el, azaz a zenei élmény (vagy annak visszajelzése) terén komoly deficitek mutatkoztak (például residualis szkizofrénia, 2. ábra), illetve az egyes dimenziók mentén az extrém megítéléseket (például a mániás vagy depressziós hangulatzavart mutató betegek az $f$-és a $b$-tengelyen jeleztek néhány torzult megítélést). Érdekesség, hogy az orvostanhallgatók és a zenemúvészeti hallgatók csak alig különböztek a pszichometriai skála szerint: a Bach-zenét az utóbbiak magasabbra helyezték (pozitívabb érték) az é-tengelyen [19].

Trost és mtsai [20] változatos zenéket alkalmazva az emóciók széles skáláján történt visszajelzéseket agyi fMR-aktivitásokkal vetették össze. A 27 zenei részletet hármasával a 'Geneva Emotional Music Scale' legillőbb 9 domináns érzelméhez csoportosították. Az emocionális értékelések faktoranalízissel két komponenst mutattak; az izgalom ('arousal', A) és az értékítélet ('valence', $\mathrm{V})$ alacsony (-) vagy magas (+) fokának megfelelően a domináns emóciók kvadránsokba osztályozódtak $(\mathrm{A}+\mathrm{V}+$ : csoda, öröm, erő; $\mathrm{A}+\mathrm{V}-$ : feszültség; $\mathrm{A}-\mathrm{V}+$ : gyengédség, békesség, transzcendencia, nosztalgia; A-V-: szomorúság). fMR-vizsgálattal azt találták, hogy magas izgalmú pozitív érzelmek $(\mathrm{A}+\mathrm{V}+)$ a bal oldali striatum és insula aktivitásával korreláltak, míg az alacsony izgalmú pozitív emóciók $(\mathrm{A}-\mathrm{V}+)$ a jobb oldali striatum és orbitofrontalis cortex aktivitásával. A pozitív/negatív kategóriától függetlenül az A+ érzelmek a szenzoros és a motoros kéreg aktivációival is mutattak összefüggést, míg az A- emóciók a ventrolateralis praefrontalis cortex és a hippocampus fMR-aktivációival [20].

\section{Zenehatás limerick}

Egyes zenékben kevés az értelem,

Míg mások bonyolultsága végtelen.

Az egyén megéli,

A müszer megméri,

Hogy bolydul mindkettôre az érzelem.

\section{$(j z)$}

\section{Zene és genetika}

Az emberek képesek a zenében foglalt hangmagasság, hangszín, időtartam, ritmus, szerkezet és hangerősség felismerésére és megértésére. Az ezen képességek megítélésére kifejlesztett mérőeszköszök ('Disturted Tunes Test', 'Karma Music Test', 'Seashore Test for Pitch, for Time') alkalmasak a zenei képzésben nem részesült személyek adottságainak felmérésére, akik relatíve magas 
pontszámokat érnek el ezeken a teszteken. Ez azt jelzi, hogy zenei tanulás és képzettség nélkül is vannak bizonyos veleszületett tulajdonságok, hogy valaki zenét tudjon hallgatni. Tudvalevően a zenei képesség halmozódik családokban, de vajon genetikai vagy környezeti faktorok számítanak-e ebben? Finnországi professzionális zenészek több mint felében az egyik vagy mindkét szülő szintén zenész volt [21].

A zenei hangmagasság felismerésében genetikai faktorok szerepet játszanak. Egypetéjű ( $\mathrm{MZ}, \mathrm{n}=136)$ és kétpetéjü (DZ, n = 148) ikerpárok a 'népszerü melódiák eltorzítása' teszt ('Distorted Tunes Test') nem odaillő hangjainak felismerésében eltérő konkordancia (C)-rátát mutattak (azaz hogy az ikerpár mindkét tagja azonos választ ad). Az egypetéjü ikreknél (MZ, azonos genetikai állomány) a C-érték 0,67 (CMZ, konkordáns monozigótaráta) volt, azaz a vizsgált egypetéjű ikerpárok 67\%ában az ikerpár mindkét tagja azonos választ adott (33\%uk eltérôt). A kétpetéjüeknél (DZ) ugyanakkor a C-érték 0,44-nak (CDZ, konkordáns dizigótaráta) adódott, azaz a kétpetéjüek csak 44\%-ban mutattak egyezést (56\%-ban viszont eltérést). Az additív öröklődési modellel számítva az öröklődési ráta $0,7-0,8$-nek adódott, ami az öröklődési tényezők meghatározó szerepét jelezte.

Svédországi ikerkutatásokkal is az derült ki, hogy a zenei képesség öröklődő, ami genetikai szempontból ugyanakkor multifaktoriális komplex kognitív jelenség, s benne a genetikának és a környezetnek a sajátos egymásra hatása tükröződik. A fenotípus biológiai hátterét nem ismerő, hipotézismentes, a teljes genomra kiterjedő molekuláris genetikai vizsgálatok több putatív gént sugallnak, amelyek esetleg hozzájárulhatnak a zenei képesség kialakításához, valamint a zene percepciója és előadása kapcsán megváltozhat a kifejeződésük.

Ilyen gének a következők: GATA2 (GATA-binding protein 2), PCDH7 (protocadherin 7), PCDH15 (protocadherin 15), CHRNA9 (cholinergic receptor, nicotinic, 9), KCTD8 (potassium channel tetramerization domain containing 8), PDGFRA (platelet-derived growth factor receptor, polypeptide), $\mathrm{PHOX} 2 \mathrm{~B}$ (paired-like homeobox 2b), CDH5 (cadherin 5, type 2), PCDHA1-9 (protocadherin- $\alpha$ gene cluster 1-9), SNCA ( $\alpha$-synuclein), FOXP2 (forkhead box P2), PPP2R3A (protein phosphatase 2 regulatory subunit $\mathrm{B} \alpha$ ), GPR 98 (VLGR 1) (member of the $\mathrm{G}$ protein-coupled receptor superfamily), USH2 (usherin), RGS2, RGS9 (regulator of G protein signaling gene family), GZMA (granzymes), GRIN2B (subunit of NMDA receptor), FOXPI (forkhead box Pl), VLDLR (very-low-density lipoprotein receptor), valamint a közvetlen korai válaszú gének: FOS (C-fos proto-oncogene), DUSPI (dual-specificity phosphatase 1), ZNF223 (zinc finger protein 223 ) és $E G R I$ (early gene response 1 gene alias $Z E N K)$.
Ezek körül néhány a belső fül, cochlea, szőrsejt (például GATA2, PCDH7, PCDH15, CHRNA9, KCTD8, PDGFRA, USH2) vagy bizonyos agyterületek (amygdala, striatum, hippocampus, colliculus inferior, auditoros thalamus) fejlődésében vesz részt, illetve ezen régiókban fejeződik ki, mások neurotranszmitterekhez (dopamin, SNCA; szerotonin), jelátvitelhez (RGS2, RGS9), synaptogenesishez, neuralis és synapticus plaszticitáshoz, nyelvi fejlődéshez (például FOXP2, FOX1), kognitív funkciókhoz, tanuláshoz, memóriához, jutalmazáshoz vagy neurodegenerációhoz (GZMA), halláskárosodáshoz (PCDH15, CDH5, USH2), Parkinson-kórhoz és Lewy-testes dementiához ( $S N C A$ ), illetve énekesmadarakban a vokalizációhoz és tanuláshoz (VLDLR, FOXP1, FOXP2, GRIN2B, RGS2, RGS9, GPR98, SNCA) köthetők [21].

Kétórás koncert után professzionális zenészek vérmintáit elemezve bizonyos gének RNS-kifejeződés-emelkedését figyelték meg (GATA2, SNCA, ZNF223, PPP2R3A), amelyek közül néhány kapcsolatba hozható a dopaminrendszerrel ( $c f$. $\alpha$-szinuklein Parkinson-kórban és Lewytestes dementiában). Zene hallgatása kapcsán ugyanakkor a ZNF223 és PPP2R3A gének alulkifejeződése volt jellemző, miként énekesmadarakban is, a FOS és DUSP2 gének expressziója csak ének produkálása után kifejezettebb (hallgatása után nem).

A zenei képességek genetikai vizsgálatai során továbbá az arginin-vazopresszin-receptor-1A génnek (lokalizáció: a 12-es kromoszóma hosszú karja, 12q14; funkció: memória), a protokadherin- $\alpha$-nak $(P C D H \alpha, 5 q 31.1$; adhézió, fejlődés), valamint az UGT8-nak (UDP-glikoziltranszferáz-8, 4q23-q26; myelin), míg abszolút hallásban a 8-as kromoszóma hosszú karjának (8q24.2) a szerepe merült fel. A 7-es kromoszóma hosszú karján lokalizálódó FOXP2-gén más gének kifejeződését modulálja. Mutációja súlyos beszédzavart okoz (verbális apraxia, egyéb motoros és szenzoros dysphasia). A FOXP2-gén több mutációja ismeretes, az egyik egy többgenerációs családfa 15 rokonában (KE család) leírt és alaposan vizsgált, mivel itt a zenei ritmus percepciójának és létrehozásának zavara áll fenn, ugyanakkor a hangmagassággal (dallam) kapcsolatos képességek megtartottak.

Morley és mtsai [22] amatőr kórustag énekeseknek (n = 258) és zenével nem foglalkozóknak ( $\mathrm{n}=261$, kórházi személyzet) a genetikai vizsgálatát végezte el Londonban az arginin-vazopresszin-receptor és a szerotonintranszporter (= SLC6A4, solute carrier 6A4) gének polimorfizmusai tekintetében. Különbséget az SLC6A4-gén 2. intronjában lévő VNTR- ('variable number of tandem repeats') polimorfizmus terén találtak: a 10 -es ismétlődésú allélok szignifikánsan ritkábbnak (esélyhányados 0,73), a 9-es (esélyhányados 2,47) és 12-es ismétlődésű allélok pedig szignifikánsan gyakoribbnak adódtak a kórustag énekesek csoportjában [22]. 


\section{Zene és orvoslástörténelem}

Lélekerősítő vagy gyógyító célzatú zenei intervenciókra utaló tárgyi emlékek vagy feljegyzések régóta ismertek. Az ókori olimpiai játékokon a versenyző́k lelkesítésére és küzdôszellemük erősítésére lantos (lyra) és fuvolás (tibia) zenészek játékait használták [23]. A Bibliában szereplő (i. e. 1000-ből eredő) történet szerint Saul királyt Dávid a lantjának pengetésével hozta jobb lelkiállapotba (1. Sam. 16, 14-23): „És valahányszor megszállta Sault Istennek az a rossz szelleme, fogta Dávid a lantot, és pengette a kezével. Saul ilyenkor megkönnyebbült, jobban lett, és a rossz szellem eltávozott tóle." Püthagorasz (i. e. 570-495) szerint a diatonikus, kromatikus, enharmonikus skálák alapvetően érintik a lelket. Platón (i. e. 428-348) lélekszerkezet, zenei intervallumok és égitestek vetületei között vélt párhuzamot ('Timaiosz' címú múve), az orvos Aszklépiadész (i. e. 124-56) a rosszkedv gyógyítására a modális fríg hangnemet (E-E zenei hangskála: mi-fá-szó-lá-ti-dó-ré-mi) ajánlotta a többi modális hangnemmel (ion: $\mathrm{C}-\mathrm{C}$, dór: $\mathrm{D}-\mathrm{D}$, líd: $\mathrm{F}-\mathrm{F}$, mixolíd: $\mathrm{G}-\mathrm{G}$ és eol: $\mathrm{A}-\mathrm{A})$ szemben.

Boethius (480-525) szerint a zene erôs hatást gyakorol az emberre ('De institutione musica'), míg az arab medicina a IX. századtól az orvos mellett egy zenész asszisztenst alkalmazott, és kijelentette, hogy gyógyítás céljára a zene legyen kellemes és szép. $J$. Tinctoris (1435-1511) a zene 20 hatását írta le, amelyek közül csak néhány: 'Musica Deum delectat' (Istent gyönyörködteti), 'Musica tristitiam repellit' (bánatot elúzi), 'Musica homines laetificat' (embereket felvidítja), 'Musica aegrotos sanat' (betegeket gyógyítja), 'Musica amorem allicit' (szerelmet lobbant).

A. von Nettesheim (1486-1535) szerint a zene fenntartja a testi egészséget, erősíti az erkölcsöt, a zenének csodálatos hatásai vannak ('De Occulta Philosophia'): „...ipsas quoque bestias, serpentes, volucres, delphines, ad auditum suae modulationis provocat ... magna vis est musica" (összefoglalva: még az állatokat is megszelídíti). J. Wittich (1537-1596) arnstadti orvos meglátása szerint az egészséghez az elégedetlenség elúzése és a szív felvidítása kell, de különösen 5 dolog: (1) 'Gottes Wort' (Isten szava), (2) 'Ein gutes Gewissen' (tiszta lelkiismeret), (3) 'Die Musica' (zene), (4) 'Ein guter Wein' (jó bor), (5) 'Ein vernünftig Weib' (értelmes feleség)". Descartes (1596-1650) úgy tartotta, hogy ugyanaz a zene, amely táncra perdít embereket, másokat sírásra fakaszthat gondolatai vagy emlékei felidézése révén.

V. Fülöp (1683-1746) spanyol király (bipoláris) depreszsziójának gyógyítására felesége, Farnese Erzsébet (16921766) 1737-ben Madridba hívatta a híres C. B. Farinelli (1705-1782) kasztrált énekest, aki 10 évig minden éj- szaka énekelt 4 áriát a király melankóliájának elúzésére (összesen 3600 alkalommal); a király kedvence a Quell'usignolo ária volt G. Giacomelli (1692-1740) Merope címú operájából (1734). A francia 'Encyclopédie' (1745) megadja azon betegségek listáját, amelyekre a zene jó hatású lehet: köszvényes fájdalom, epilepszia, szorongás, depresszió, mentális betegek zajongása, láz, pestis. E. A. Nicolai (1722-1802), a Jénai Egyetem orvosprofesszora leírásában: „...zene hallgatására a szőrszálak felállnak (piloerectio), a vér kimegy a felszíni részekről, a bőr húvössé válik, a szív gyorsabban ver, a légzés lassúbb és mélyebb..." F. A. Weber (1753-1806, orvos, zeneszerző, Heilbronn, 1802) így látja: „...a zene csak idegbetegségekre lehet jó... impotenciát nem gyógyít... persze a házastársi gyengédség növelésével erre is hathat." Az ismert legendás (bár nem biztos, hogy igaz) történet szerint $H$. C. von Keyserlingk orosz diplomata álmatlanságban szenvedett, és $J$. S. Bachot kérte zene megírására, amely segíthet az állapotán. Titkára, J. G. Goldberg játszotta neki éjszakánként, innen a mú elnevezése: 'Goldberg-variációk', amely 2 áriából és 30 variációból áll, és 1741 táján keletkezett.

J.-É. D. Esquirol (1772-1840) francia elmeorvos vélekedésében az egyéni és csoportos zeneterápia hatása időleges. A zeneterápia hatását illető kétkedések is megmegjelentek azonban, például már a III. században (Quintus Serenus) vagy Athanasius Kircher (1650) szkepticizmusában: „...lehetetlennek tartom, hogy a tïdővészest, az epilepsziást vagy a köszvényest zenével gyógyítani lehetne." Eduard Hanslick (1825-1904) híres (hírhedt) osztrák zenekritikus írásában ez áll: „...a zene fizikális hatása nem elég erôs és konzisztens, nem mentes a pszichikai és esztétikai előfeltételektől, és szabadon nem alkalmazható mint valódi orvosi kezelés" ('Vom Musikalisch-Schönen', 1854). A modern kor a zene hatásának experimentális és tudományos igényú megközelítéseivel számos adatot szolgáltatott a témát illetően, amely adathalmazt újabban metaelemzések segítségével próbálják kitisztítani és valamelyest egyértelmúvé tenni $[7,23]$.

\section{A zene szomatikus hatásai}

Filogenetikusan az akusztikus rendszer a vestibularisból fejlődött, és a nervus vestibularis jelentős számban akusztikus ingerre érzékeny rostokat is tartalmaz. A sacculus és az utriculus vibrációra és hangra is érzékeny, és a vestibularis magcsoport erôs, mély vagy hirtelen kezdetû́ hangokra válaszul hatást gyakorol a spinalis és szemmozgató motoneuronokra. A vestibularis és cochlearis magok továbbá a formatio reticularisba rostokat adnak, valamint az előbbi a nucleus parabrachialisba is, amely a vestibularis, visceralis és vegetatín idegrendszeri feldolgozás színhelye. Ilyen projekciókkal a zene mozgási és autonóm idegrendszeri hatásait subcorticalis szinten tudja indítani és fenntartani, tehát a hangingerek akusztikus élménye mellett a szervezet motoros és vegetatív válasz- 
reakciót képes szabályozni. Ezeknek a mechanizmusoknak a lassú ütemre történő akaratlan együttmozgásban szerepe lehet [1]. A zene által kiváltott emocionális $i z-$ galmi állapot ('arousal') és bizsergés ('chills') érzésének intenzitása szignifikáns korrelációt mutatott pszichofiziológiai paraméterek csökkenésével (bőrellenállás, testhőmérséklet, vértérfogat, pulzusamplitúdó) vagy növekedésével (szívritmus, légzésszám). Mindezen változások fokozott vegetatív szimpatikus idegrendszeri aktivitásra utalnak, és jelzik, hogy a bizsergés (lúdbőr) érzése megfelelő jelzője az emocionális izgalmi állapot tetőpontjának [13].

A zenei, cardiovascularis és cerebrális ritmusok dinamikus kölcsönhatását vizsgálták 24 fiatal egészséges (12 zenész/kórustag, 12 nem zenész) önkéntes személyben [24]. Random sorrendben progresszív crescendo zenék (vokális: Puccini: Turandot, zenekari: Beethoven: IX. szimfónia - Adagio), egyenletes (J. S. Bach kantátája), 10 mp-es ritmusos részek (Verdi: Va, pensiero - Nabucco, Libiamo ne'lieti calici - Traviata) vagy csend következtek, és a szívritmust, a vérnyomást (szisztolés, diasztolés), a légzést, az arteria cerebri media áramlási sebességét és a bőr vasomotoros jeleit (bőrellenállás) regisztrálták. Nem volt különbség zenészek és nem zenészek között a fiziológiai eredményekben. Azt találták, hogy a zenére adott válasz szubjektív, de az individuális preferenciától függetlenül a cardiovascularis változók emelkednek a zenei tempó gyorsulásával. A crescendók érintették a vérnyomást és a bőrvasodilatatiót, a Verdiritmusok pedig szinkronizálták, ritmusba hozták a cardiovascularis vegetatív paramétereket ('entrainment', Mayer-hullámok).

Ugyanezen kutatócsoport az alkalmazott orgonamuzsika-részletek (J. S. Bach, Boëllmann, Quaroni, Monk, da Bergamo) passzív hallgatásának hatására zenészekben és nem zenész személyekben az autonóm vegetatív idegrendszeri ritmusok szinkronizációjának növekedését észlelte a szívritmus, a légzés, a vérnyomás (radialis arteria) és a perifériás vérkeringés (ujjak) monitorozása kapcsán [25]. A zenehallgatás előtti alaphelyzethez ('baseline') képest az élettani ritmusok csoportszinkronizációja és koherenciaemelkedése volt jellemző, amely természetesen különbözött az egyes orgonamuzsika-daraboknál. Azt is megfigyelték, hogy az egyénileg kellemesnek ítélt zenei karakter javította, míg a hangerő változékonysága (főként a hangosság!) rontotta az élettani paraméterek csoportszinkronizációját [25].

\section{Énekes limerick}

Agynak és fának éltetō a kéreg; Az opera nézöterén meg méreg, Mikor az ének-est Fölléptet énekest, Ki ordit, mint a fába szorult féreg.

\section{$(j z)$}

A zene különféle biomarkerekkel alátámasztott pszichoneuroimmunológiai vonatkozásairól 2003-ig 23, majd 2003 és 2013 között 40 közlemény jelent meg. Egy 63 tanulmányt magában foglaló metaelemzés szisztematikusan tárgyalja a zeneterápia szomatikus hatásait, különös figyelmet szentelve az endokrin és pszichoneuroimmunológiai paramétereknek [26]. A metaelemzés a kortizol, az adrenalin, a noradrenalin és a $\beta$-endorfin anyagok termelődésének csökkenésére, míg az oxitocin és a gonadotrop hormon szintjének növekedésére konkludál az adatok összesítése tükrében. A metaelemzést jobban részletezve, a vizsgálatok zömében (a 25-ből 22) a pszichológiai tesztekkel mért szorongás mértékével parallel és szignifikáns módon csökkent a szérum kortizolszintje relaxáló karakterü gépi zene (lemez) hallgatása után. Hasonló típusú, lassú tempójú zene a vitális élettani paraméterek közül 20 vizsgálatból 16-ban csökkentette a vérnyomást, a szívritmust és a légzésszámot. A szimpatikus idegrendszeri aktivitás csökkenése révén néhány vizsgálatban a bőrellenállás is lejjebb ment. Csak a kortizolra összpontosítva, a 29 vizsgálatból 18 a kortizol szintjének csökkenéséról számol be mind aktív zenei részvétel, mind gépi zene hallgatása után. A zene megválasztása fontos, a hatás szempontjától a személy individuális zenei választása az ideális (ahhoz a helyzethez képest, amikor a vizsgálatvezető teszi mindezt). Abban már megoszlottak a vizsgálati eredmények, hogy a stimuláló zene hatása milyen; leírtak kortizolemelkedést is, amelyet ACTH-, növekedésihormon- és adrenalinemelkedés is kísért.

Egyéb hormonok tekintetében relaxáló zenére oxitocinemelkedést találtak, valamint tesztoszteronemelkedést férfiakban és -csökkenést nőkben. A fehérvérsejtek és citokinek mérése területén változó eredmények születtek; leginkább az interleukin-6 reagált a relaxáló zenére, 5 vizsgálatból 4-ben szignifikánsan csökkent. Az immunglobulin-A 12 vizsgálatból 8-ban szignifikánsan emelkedett zenei intervenciókra, fóleg ha a zene kedvelt volt, vagy ha a személy aktívan részt vett a zenei produkcióban. A 3. ábra a zene lehetséges pszichoneuroimmunológiai hatásait foglalja össze Fancourt és mtsai [26] alapján. Súlyos sérülés kiváltotta hipermetabolikus szindróma enyhítésében is lehetséges a zene szerepe: csökkentheti a hormonális és a metabolikus funkció felborulását a katecholaminok, a glükagon, a kortizol és a gyulladásos citokinek termelődésének redukálása révén, aminek következtében csökken az inzulinrezisztencia, a glikoneogenezis, a lipolízis és a proteolízis.

\section{Zenehallgatás testi betegségekben}

Mütéti beavatkozások előtt a passzív zenehallgatásnak szorongást csökkentő hatása lehet. Egy Cochrane-metaanalízis 26 tanulmányt elemzett $(\mathrm{n}=2051)$, és megállapította, hogy a nemzetközileg elfogadott és használt szorongásskálán ('State-Trait Anxiety Inventory') átlagosan 5,72 egységgel mértek kevesebbet (egyéb tesztekkel is 


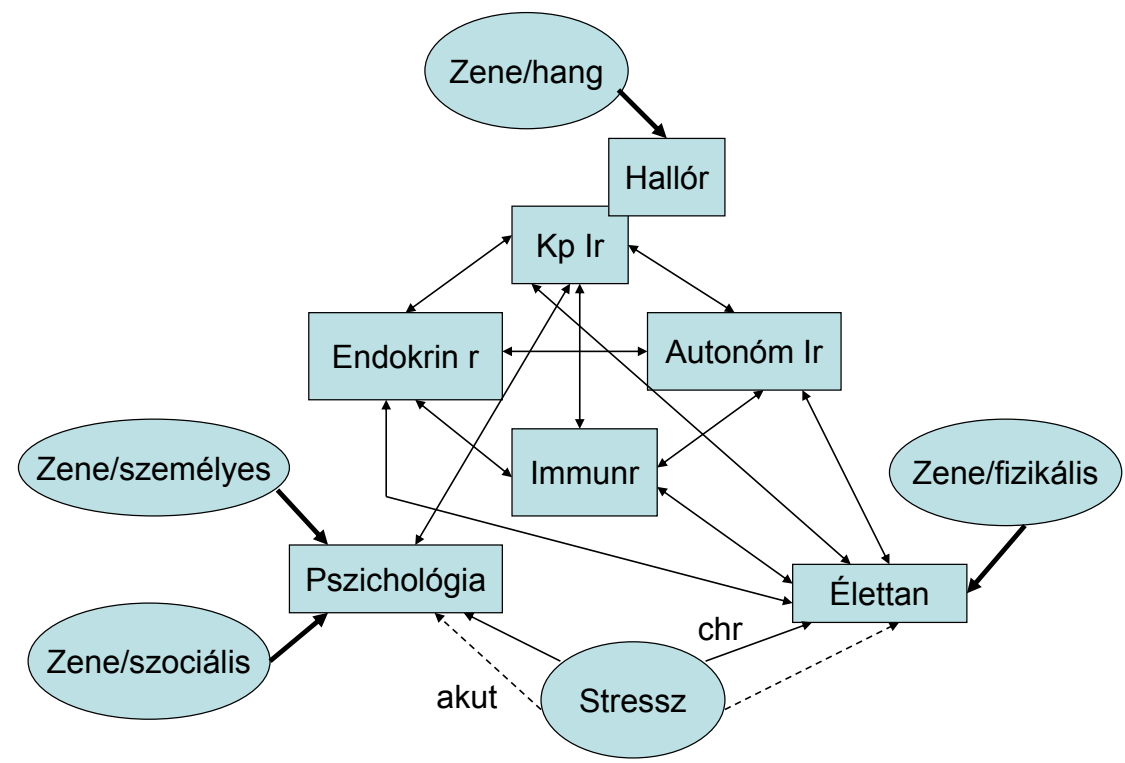

3. ábra A zenére adott pszichoneuroimmunológiai és endokrinológiai válaszreakciókban valószínúsíthetően szereplő rendszerkölcsönhatások modellje Fan-
court és mtsai [26] tanulmányok ( $\mathrm{n}=63$ ) metaelemzése után kialakított koncepciója alapján. A zene/hang a perifériás hallórendszeren át a hallókéreg-
be és a központi idegrendszer (Kp Ir) további területeibe eljutva érinti az autonóm vegetatív idegrendszert (Ir), az immun- és endokrin rendszert, a
szomatikus élettani folyamatokat, valamint a pszichológiai reakciókat. A kétirányú nyilak a kölcsönös egymásra hatást hangsúlyozzák. A zenének léte-
zik egy személyes (egyedüllétben kifejezett), valamint társaságban érzett és manifesztálódó komponense; mindkettő pszichológiai természetú, de
vannak a szomatikus fiziológiát direkt módon érintő jellegzetességeik (például hangeró, cf. szöveg, A zene szomatikus hatásai címú fejezet), amelyek
mind befolyásolják a Kp Ir-t és áttételesen vagy közvetlenül az immun- és endokrin rendszert, illetve az autonóm Ir-t. A stressz (az akut is, de külö-
nösen a krónikus [chr] kiszámíthatatlan típus) a pszichológiai és a testi élettani funkciókra egyaránt kihat. A metaelemzés kimutatása szerint
zeneterápiára vagy zenei intervencióra a mérhetó biológiai paraméterek közül (cf. szöveg) kiemelhetó a kortizol (stresszhormon), az adrenalin, a nor-
adrenalin és az interleukin-6 csökkenése, valamint az oxitocin, a gonadotrop hormon, a tesztoszteron (férfiakban) és az immunglobulin-A növekedése
[26]

redukció volt észlelhető); a szívritmus és a diasztolés vérnyomás csökkent, a szisztolés azonban nem, miként a légzésszám és a bőrhőmérséklet sem. A Cochrane-elemzés felhívja azonban a figyelmet a metodikai nehézségekre és arra, hogy az eredményeket óvatosan kell kezelni. Ugyanakkor három korábbi Cochrane-tanulmány konklúziójával egybevágnak az adatok, hogy szomatikus betegségekben a zene jótékony hatású a szorongás csökkentése szempontjából [27]. Ha az élettani paraméterekre kifejtett hatás vita tárgyát képezheti is, a zene biztosította kellemes, csendes, relaxáló környezet anxietast oldó ereje nyilvánvaló.

Perioperatín zenehallgatás a stresszel kapcsolatos vérnyomáskiugrásokra és a megküzdő ('coping') pszichológiai mechanizmusokra jó hatással volt kontrollszemélyekkel összehasonlításban. Perioperatív zenehallgatás szívmütéteknél is hasznos stresszcsökkentőnek bizonyult; 30 perc ágynyugalom után a zenét hallgató csoportban a szérumkortizolszint $484,4 \mathrm{mmol} / 1$ volt, míg a zenét nem hallgató csoportban $618,8 \mathrm{mmol} / \mathrm{l}$; a különbség szignifikánsnak bizonyult $(\mathrm{p}<0,02)$. Természetesen az individuálisan kedvelt zene megválasztása fontos tényező [23]. Kontrollált randomizált vizsgálatok metaelemzése szívkatéterezés kapcsán jelzi a zenének a szorongáscsökkentő jellegén keresztül érvényesülő enyhe jótékony hatását [28].

Sebészeti beavatkozásoknál a stressz és a szorongás fokozza a fájdalomérzetet. A fájdalom mérséklésében, mint adjuváns, szerepe lehet a zenének, csökkentve ezál- tal a fájdalomcsillapító gyógyszerek iránti igényt. A zene kiválasztása fontos, a hatékonyság tekintetében általában a beteg preferenciájára érdemes hagyatkozni inkább, mint másokéra. Clevelandből származó tanulmány elektív ortopéd sebészeti mütétek $(\mathrm{n}=163)$ során írta le a zene kedvező befolyását a fájdalomra és az emocionális állapotra (hangulat, szorongás). Küblmann és mtsai [29] metaelemzése is a zenének a szorongásra és a fájdalomszintre kifejtett pozitív jellegét foglalja össze [29]. Számos közlemény számol be az ambulanter urológiai beavatkozások során alkalmazott zenehallgatásnak az anxietasra és a fájdalomra gyakorolt mérséklő hatásáról, amelyet metaelemzés is összegez [30]. A daganatos betegek standard kezelése mellett beállított zenei beavatkozás egy közelmúltbeli metaelemzés szerint a csak szokásos onkológiai terápiában részesültekhez képest javította az életminőséget, a hangulatot és a lelki életet ('spirit'), növelte az ellazultságot (relaxáció), valamint csökkentette a depressziót, a szorongást, a distresszt, a fájdalmat és a fáradtságot [31].

Az agyi érkatasztrófa (stroke) utáni neurológiai rehabilitációnak is részét képezheti a zenealapú intervenció, amely különféle agyterületek (homlok- és fali lebeny, motoros és szomatoszenzoros cortex, hallókéreg, colliculus inferior, planum temporale, g. angularis, cerebellum, amygdala, nucleus accumbens, thalamus, insula, praecuneus, hippocampus, ventralis tegmentalis area, striatum, g. cingularis) múködését érintheti. A cerebrális aktivitás növekedése javíthatja a stroke-ot szenvedett agy 
vérkeringését, a hypothalamus-agytörzs-vegetatív idegrendszeri úton befolyásolhatja a szívmúködést, a hypothalamus-hypophysis-mellékvese tengelyen keresztül pedig csökkentheti a kortizol stresszhormon termelődését. A stroke utáni napi zenehallgatás, hangoskönyv a csak standard terápiás csoportokkal 3 és 6 hónap múlva összehasonlítva javította a memória- és figyelmi funkciókat, a depressziós tüneteket, valamint a konfúziót. Az állapotokat fMR- és MEG-vizsgálatokkal is követték, és a cerebrum egyes területein (kétoldali g. temporalis superior, bal oldali ventralis/subgenualis elülső g. cinguli) a zenét hallgató személyekben a másik két csoporthoz képest magasabb aktivációkat észleltek [32].

Torontóban és a Stanford Egyetemen krónikus strokebetegekben figyelték a motoros, a kognitív és a pszichoszociális funkciók változását zenetámogatott terápia $(\mathrm{n}=$ 14) hatására a konvencionális kezeléssel ( $\mathrm{n}=14$ ) összehasonlításban. Tízhetes kezelés mindkét csoportban javulást eredményezett ('Chedoke-McMaster Stroke Assessment'), de bizonyos tesztek végrehajtására a zenei csoportban kevesebb idő kellett. Az emocionális, közérzeti-életminőségi és szociális kommunikációs mérőeszközök is korábbi javulást jeleztek a zenével támogatott krónikus stroke-csoportban [33]. Agyi érkatasztrófa után fél évvel a kimutatások szerint a betegek mintegy 12\%-nál észlelhető valamilyen típusú és fokú beszédzavar, aphasia. A beszédnek és az éneklésnek jelentős agyterületi átfedései vannak, így talán nem meglepő, hogy motoros aphasiában (a Broca motoros beszédközpont sérülése, általában a bal oldali Br. 45-44-es area a homloklebenyben, 1. ábra) az éneklés gyakorlásának, a dallamalapú intonációs kezelésnek ('Melodic Intonation Therapy') komoly szerepe van a beszédzavar, az aphasiás tünetek gyógyításában, amit számos közlemény alátámaszt [34].

\section{A zene mentális hatásai}

A lélekre gyakorolt hatásai miatt a zene különféle formáit ősidők óta próbálgatták a helyzettől függően nyugtatásra, vagy éppen ellenkezően, stimulálásra (a gyújtó hatású daloknak és hangszeres zenéknek az egyénre és a közösségre kifejtett ereje ismeretes különféle alkalmakkor). Érthetően a mentális zavarok kezelésében és főként rehabilitációjában a zeneterápia (passzív, aktív formában egyaránt) kiemelt jelentőséget kap világszerte. Példaként említve, a poszttraumás stresszzavar (PTSD) mind a négy tünetcsoportjának (intrúzió, elkerülő viselkedés, negatív hangulat/kogníció, izgalmi állapot) csökkentésére alkalmas [35]. Autizmus-spektrumzavar esetén a szociális szférában mutatott emocionális kommunikációs hiányt a zene javíthatja, egyfajta különleges ablakot nyit a világra. Az élet bizonyos időszakainak megváltozott élettani állapotaiban, például graviditás, is jótékony hatású lehet. A zenehallgatás a várandós nők általános, graviditáshoz köthető, valamint az anyaság érzésével összefüggő stressz-szintjét egyaránt kedvezően befolyásolta.
Felmerül a kérdés, hogy egészséges egyének bizonyos kognití múködéseire miként hathat a zene. Rauscher és mtsai [36] egyetemi hallgatók ( $\mathrm{n}=36$, University of California, Irvine) három csoportját képezte; az egyik 10 percig Mozart D-dúr kétzongorás szonátáját (K. 448), a másik relaxációs zenét hallgatott, a harmadik pedig csendben töltötte az időt. Késedelem nélkül, rögtön ezután a térbeli gondolkodás ('spatial reasoning') egy tesztjét töltötték ki (Stanford-Binet Intelligencia Skála altesztje), ahol azon eredmény született, hogy a Mozartzenét hallgatók 8-9 ponttal jobb teljesítményt nyújtottak, ami nem az éberség ('arousal') emelkedésével függött össze [36]. (Az úgynevezett 'Mozart-hatást' először Alfred A. Tomatis írta le 1991-ben megjelent könyvében: 'Pourquoi Mozart?’ [Miért Mozart?]). A közlemény nagy vitákat váltott ki, többen félreértelmezték, és hosszú hatást is reméltek tőle, valamint a média is nagy hírveréssel felkapta, illetve rendre torzítva interpretálta. A kísérletet többeknek nem sikerült megismételniük, és erősen kétségbe vonták.

Míg a kérdéses Mozart-zenének a kognitív funkciót javító hatásáról erősen megoszlanak a vélemények, egy másik vonulatban elkezdték használni: epilepsziában EEG-vel alátámasztva számos vizsgálatban megerősítették jótékony hatását [37]. A közelmúltban is skót szerzők epilepsziás gyermekek ( $\mathrm{N}=45,2-18$ év életkori tartomány) epileptiform EEG-aktivitását vizsgálták a fent említett Mozart kétzongorás szonáta hallgatása alatt, életkorhoz igazított kontrollzene alatti aktivitással összehasonlításban. Öt egymás utáni mérésben (alaphelyzet, Mozart-zene, 2 zene közötti szünet, kontrollzene, utána, egyenként 5 perc). Az EEG-n az epilepsziás kisülések frekvenciájának szignifikáns $(\mathrm{p}<0,0005)$ csökkenését észlelték az alaphelyzethez képest. Olasz szerzők a kétzongorás szonátát egyéb, random választott Mozart-múvek hatásával vetették össze gyógyszerrezisztens gyermekkori epilepsziában ( $n=19)$, és azt találták, hogy az egyéb kompozíciók még inkább hatékonyak voltak az epilepsziás rohamok mitigálásában, emiatt a zeneterápiát a rezisztens epilepsziában nem farmakológiai kiegészítő kezelésként ajánlják [38].

Belátható, hogy az aktuális hangulati fekvés befolyásolja a zenei preferenciát. Egyetemi hallgatók $(n=49)$ körében végzett tanulmány szerint az akaratlagosan indukált, teszttel ('Positive and Negative Affect Schedule') verifikált negatív vagy pozitív emóciók (szomorú és vidám emlékek) úgy hatottak, hogy rossz hangulatban szomorú (és lassú) zenét választottak, vidám hangulatban boldog karakterüt, és averzió volt a szomorú zenével szemben (fordítva viszont nem) - azaz a hangulat értékítéletet közvetített [39]. A zenei háttér a memóriát is befolyásolhatja. Önkéntes egészséges fiatal személyek- 
ben $(\mathrm{n}=48)$ míg a vidám típusú háttérzene a pozitív jellegü (vidám) arckifejezések (képek) felidéző emlékezését nem befolyásolta, addig a szomorú zene rontotta azt. Negatív (bánatos) arcok felidézését viszont a vidám zene rontotta, a szomorú azonban nem befolyásolta, tehát hasonló, de fordítottan volt azonos a helyzet a zene és a képi memória emocionális jellege között; a hasonló a hasonlót kedveli (similis simili gaudet), az ellentétes karakterek viszont rontják egymást [40].

Miként más típusú mentális vagy szomatikus betegségben, a hangulattal kapcsolatosan kiemelendő, hogy a megfelelően és individuálisan megválasztott zenének jelentősége van. Már a Bibliában olvasható hogy „mint aki leveti ruháját hideg időben, vagy mint aki ecetet kever lúggal, olyan az, aki a rosszkedvü ember előtt dalol" (Péld. 25,20). Pszichoterápiás beavatkozásokkal ( $\mathrm{n}=$ $38)$ összevetve a zeneterápia $(\mathrm{n}=4 \mathrm{l})$ hatását kedvezőbbnek találták mexikói depressziós betegekben; az ülések befejeztével a pszichoterápiás csoport több mint fele nem javult, míg a zeneterápiás csoportban csak közel 14\% nem. Az alkalmazott zenék a következők voltak: Bach: Olasz koncert, BWV 971; Corelli: D-dúr concerto grosso, op. 6; Mozart: D-dúr kétzongorás szonáta, K. 448 [41].

Háromkarú randomizált kontrollált vizsgálattal postnatalis depressziós anyákban $(\mathrm{n}=134) 10$ hetes csoportos éneklés hatását elemezték másik két csoporttal (játékos program, szokásos gondozás) összehasonlításban. A postnatalis depresszió pszichometriai megítélésére kifejlesztett eszköz ('Edinburgh Postnatal Depression Scale') segítségével kvantitatív értékelés alapján kimutatva az éneklés nem szignifikáns módon gyorsabb javulást eredményezett (6. hét); a közepes-súlyos depressziós csoportban ugyanakkor ez a javulás elérte a szignifikancia szintjét a másik két populációhoz képest [42]. Metaelemzés (28 tanulmány összesen 1810 vizsgált személylyel) a passzív zenehallgatás (lemez, élő zene, 79\%) és az aktív zenei előadás (éneklés, hangszeres játék, 46\%) hatását összegezte depresszióban, amely szerint 26 vizsgálatban statisztikailag szignifikáns tünetcsökkenés volt észlelhető ezen zenei beavatkozásokkal, kontrollcsoportokkal összehasonlításban. Idősebb személyek jobban reagáltak, és az individuálishoz képest a csoportosan alkalmazott passzív vagy aktív zeneterápia kissé előnyösebb volt a hatás szempontjából [43].

Egy másik (Cochrane-) metaelemzés 9 vizsgálatot vont be 411 személlyel, és a zeneterápia szignifikáns rövid távú kedvező hatását jelezte depressziós állapotban, amennyiben a szokásosan elfogadott kezelési módszer mellett alkalmazták. A depressziós tüneteken túl a szorongáscsökkentésben is hatékonynak bizonyult. Zeneterápiás alkalmazást pszichoaktív szerfüggő személyekben is kipróbáltak, és 40 tanulmány összegzése szerint a viszonylag kisebb arányban szereplő kontrollált elrendezésekben bizonyos pszichopatológiai tüneteket jó irányban befolyásolt (motiváció, élvezet, önkontroll), ugyanakkor másokat nem változtatott meg (megvonási tünetek, só- várgás ['craving'], megküzdő mechanizmusok). A zenei ingerekre kiváltott agyi funkcionális változások képalkotó eljárásokkal történő leképezése betegcsoportokban is megtörténik. Major depresszió tüneteit mutató személy zenei percepciója és annak cerebrális hatásai megváltozottak lehetnek; erre utalnak Aust és mtsai [44] adatai. Remisszióban lévő depressziós betegeknél egészséges kontrollegyénekkel történő összehasonlításban csökkent pregenualis anterior g. cinguli fMR-aktivációt találtak kellemes zenei ingerekre a semlegesekhez viszonyítva. Semleges zenei ingerekhez képest ugyanakkor a kellemetlenek a hippocampus fMR-aktivációját váltották ki, amelyben a személyre jellemző tartós szorongásos jegyek rendelkeztek moduláló hatással (a variancia 38\%-át magyarázták) [44].

Dementiában szenvedő személyek tüneteinek és életminőségének befolyásolására is kiterjedten használják a zeneterápiát és a zenei intervenciókat. Itt is kiemelik a személyre szabott zene megválasztásának jelentőségét [45]. Enyhe-közepes dementiával élő egyénekben $(\mathrm{n}=$ 15) a zene és séta kettős tréning ('Musical Dual-Task Training') javította a figyelmi funkciókat (nyomvonalkövető teszt), csökkentette az eleséstől való félelmet és az agitált magatartást a kontrollcsoporthoz $(\mathrm{n}=13)$ képest. Van der Steen és mtsai [46] alapos és hatalmas anyagot átölelő Cochrane-metaelemzése egyértelműsíti kontrollhelyzettel összehasonlításban a zenére alapozott terápiás intervenciók kedvező hatását dementiában szenvedő személyek emocionális közérzetére, életminőségére, depressziójára, szorongására, bizonyos kognitív múködésére, agitált/agresszív és általában problémás viselkedésére, valamint közösségi magatartására [46].

\section{Zeneterápia limerick \\ A zene lebet nyugtató, bóditó, \\ Izgató, vagy áldásosan gyógyitó; \\ Stressz, kedély, szorongás, \\ Gondolat forrongás, \\ Mindre hathat-ezáltal oly' hóditó.}

\section{(jz)}

Nemcsak a zene hat a mentális állapotra, hanem fordítva is igaz, azaz mentális tényezők alapvetően befolyásolhatják a zenei produkciók minőségét, stílusát, karakterét, az előadómúvész lelkiállapota kiérződhet a darab prezentációjából. Elsősorban a hangulati élet fekvése és az emocionális rezdülések jönnek szóba e téren. Továbbmenve, a kedélyingadozások jelentősen érinthetik a zeneszerzők motivációját, alkotóerejét és kreativitását [47], amelyek a darabok karakterében is tükröződhetnek; az alkotás minőségét viszont alapvetően nem befolyásolják. Számos világhírü komponista életében előfordultak kedélyzavarra vagy hangulatkilengésre utaló periódusok (a teljesség igénye nélkül: I. Albéniz, I. Berlin, H. Berlioz, G. Bizet, J. Brahms, A. Bruckner, P. Csajkovszkij, G. Donizetti, E. Elgar, C. Gesualdo, M. Glinka, G. F. Händel, G. Holst, 
O. Klemperer, O. Lassus, G. Mahler, F. Mendelssohn, M. Muszorgszkij, G. Puccini, S. Rachmaninov, M. Reger, G. Rossini, E. Satie, R. Schumann, A. Szkrjabin, G. Verdi, R. Wagner, H. Wolf). A témában jelent meg közlemény e folyóiratban, amely részletesebben Rossini kedélyzavarát taglalja, de egyebek között érinti Händel, Mozart, Schumann, Mahler és az inkább karmester Klemperer példáit is [48].

A 'musica et medicina' témához hozzátartozik és tanulságos, hogy a zeneszerzők az évszázadok során (a társadalom közmegítélését is tükrözve) miként jelenítik meg az orvost, a doktort (és gyógyszerészt) a zenében, elsősorban az opera- vagy más zenés színpadon, a csaló kuruzslónak való feltüntetéstól a commedia dell'arte dottore karakterén át az orvos társadalmi megbecsültségének bemutatásáig. Erről is fellelhetők írások, az egyik éppen a jelen folyóiratban $[49,50]$. A témakört folytatva, számos tudós és praktizáló orvos kiváló zenészként vagy zeneszerzőként is jegyzett (néhány a sok közül: T. Billroth, H. Boerhaave, A. Borogyin, R. Brocklesby, Gábor S. P., H. L. von Helmboltz, E. Jenner, R. Kogan, Mibalik K., Németh N., A. Schweitzer, Vukán Gy., W. Withering), amire számtalan további nemzetközi és hazai példa is található, különösen az előadó-múvészetben (például Semmelweis-vonósnégyes). Többen persze elhagyták orvosi pályájukat vagy tanulmányaikat éppen a zene vagy a zeneszerzés kedvéért (például $H$. Berlioz, $F$. Kreisler, G. Sinopoli).

\section{Epilógus}

Jean Mignot, a milánói dóm építője szerint 'ars sine scientia nibil est' (a múvészet tudomány nélkül semmi), amiben igaza is volt (tudományos mérnöki tervek és kivitelezés nélkül a dóm összedőlt volna), viszont a mondás esetleg meg is fordítható: 'scientia sine arte nibil est' (jz). Ez vitatható talán, ha az 'ars' kifejezést szúkebb értelemben vesszük, de amennyiben hagyományosan (az szakértelmet, mesterségbeli tudást is jelentett), ebben a tágabb értelmezésben talán igaz is lehet. Mindazonáltal a múvészet és a tudomány számos ponton találkozik, ami a 'musica et medicina' területén is nyilvánvaló. Ezen erōfeszítéseket célozza, hogy a zene adta áldást (eudaimonia és gyógyító erő az emberiség számára) az ideg- és orvostudomány olyképpen próbálja viszonozni, hogy igyekszik megfejteni a zene felfogásának, feldolgozásának és produkciójának (létrehozásának) tudományos hátterét [7]. Végül is Apollón (Apollo) a görög-római mitológiában egyben volt (többek között) a zene és a gyógyítás istene.

Anyagi támogatás: A közlemény elkészítése és az ahhoz kapcsolódó kutató- és irodalmi munka anyagi támogatásban nem részesült.
A szerző a cikk végleges változatát elolvasta és jóváhagyta.

Érdekeltségek: A közlemény megírásában a szerzőnek nincsenek érdekeltségei.

\section{Köszönetnyilvánítás}

A közlemény a Szeged-Csanádi Egyházmegye szervezésében 2008 óta évente megrendezésre kerülő szegedi Szent Gellért Nemzetközi Zenei Fesztivál (http://szentgellertfesztival.hu) tudományos előadásai alapján készült. Az előadásokra való évenkénti felkérésért köszönetemet fejezem ki a védnöknek és a fesztiválszervezőknek.

\section{Irodalom}

[1] Koelsch S. Brain correlates of music-evoked emotions. Nat Rev Neurosci. 2014; 15: 170-180.

[2] Fitch WT. Four principles of bio-musicology. Philos Trans R Soc B Biol Sci. 2015; 370: 20140091.

[3] Gray PM, Krause B, Atema J, et al. Biology and music. The music of nature. Science 2001; 291: 52-54.

[4] Balter M. Evolution of behavior. Seeking the key to music. Science 2004; 306: 1120-1122.

[5] Patel AD, Iversen JR, Bregman MR, et al. Experimental evidence for syncronization to a musical beat in a nonhuman animal. Curr Biol. 2009; 19: 827-830.

[6] McDermott J, Hauser MD. Nonhuman primates prefer slow tempos but dislike music overall. Cognition 2007; 104: 654668.

[7] Schaefer HE. Music-evoked emotions - Current studies. Front Neurosci. 2017; 11: 600.

[8] Clark CN, Downey LE, Warren JD. Brain disorders and the biological role of music. Soc Cogn Affect Neurosci. 2015; 10: 444452 .

[9] Hyde KL, Lech J, Norton A, et al. The effects of musical training on structural brain development: a longitudinal study. Ann N Y Acad Sci. 2009; 1169: 182-186.

[10] Limb CJ. Structural and functional neural correlates of music perception. Anat Rec Part A 2006; 288A: 435-446.

[11] Pallesen KJ, Brattico E, Bailey C, et al. Emotion processing of major, minor, and dissonant chords: a functional magnetic resonance imaging study. Ann N Y Acad Sci. 2005; 1060: 450-453.

[12] Lerner Y, Papo D, Zhdanov A, et al. Eyes wide shut: amygdala mediates eyes-closed effect on emotional experience with music. PLoS ONE 2009; 4: e6230.

[13] Salimpoor VN, Benovoy M, Larcher K, et al. Anatomically distinct dopamine release during anticipation and experience of peak emotion to music. Nat Neurosci. 2011; 14: 257-262.

[14] Münte TF, Altenmüller E, Jäncke L. The musician's brain as a model of neuroplasticity. Nat Rev Neurosci. 2002; 3: 473-478.

[15] Linnavalli T, Putkinen V, Lipsanen J, et al. Music playschool enhances children's linguistic skills. Sci Rep. 2018; 8: 8767.

[16] Habibi A, Damasio A, Ilari B, et al. Music training and child development: a review of recent findings from a longitudinal study. Ann N Y Acad Sci. 2018; 1423: 73-81.

[17] Stark EA, Vuust P, Kringelbach ML. Music, dance, and other art forms: New insights into the links between hedonia (pleasure) and eudaimonia (well-being). Prog Brain Res. 2018; 237: 129152.

[18] Reybrouck M, Vuust P, Brattico E. Brain connectivity networks and the aesthetic experience of music. Brain Sci. 2018; 8: 107.

[19] Janka Z, Zöllei É, Szentistványi I, et al. Psychometric analysis by semantic differential scale of emotional experience of music. [Zenei élmény pszichometriai elemzése szemantikai differenciál ská- 
lával.] Clin Neurosci/Ideggyogy Sz. 1987; 40: 442-450. [Hungarian]

[20] Trost W, Ethofer T, Zentner M, et al. Mapping aesthetic musical emotions in the brain. Cereb Cortex 2012; 22: 2769-2783.

[21] Järvelä I. Genomics studies on musical aptitude, music perception, and practice. Ann N Y Acad Sci. 2018; 1423: 82-91.

[22] Morley AP, Narayanan M, Mines R, et al. AVPR IA and SLC6A4 polymorphisms in choral singers and non-musicians: a gene association study. PloS ONE 2012; 7: e31763.

[23] Trappe HJ. The effects of music on the cardiovascular system and cardiovascular health. Heart 2010; 96: 1868-1871.

[24] Bernardi L, Porta C, Casucci G, et al. Dynamic interactions between musical, cardiovascular, and cerebral rhythms in humans. Circulation 2009; 119: 3171-3180.

[25] Bernardi NF, Codrons E, di Leo R, et al. Increase in synchronization of autonomic rhythms between individuals when listening to music. Front Physiol. 2017; 8: 785.

[26] Fancourt D, Ockelford A, Belai A. The psychoneuroimmunological effects of music: a systematic review and a new model. Brain Behav Immun. 2014; 36: 15-26.

[27] Bradt J, Dileo C, Shim M. Music interventions for preoperative anxiety. Cochrane Database Syst Rev. 2013; 6: CD006908.

[28] Jayakar JP, Alter DA. Music for anxiety reduction in patients undergoing cardiac catheterization: a systematic review and metaanalysis of randomized controlled trials. Complement Ther Clin Pract. 2017; 28: 122-130.

[29] Kühlmann AYR, De Rooij A, Kroese LF, et al. Meta-analysis evaluating music interventions for anxiety and pain in surgery. Br J Surg. 2018; 105: 773-783.

[30] Kyriakides R, Jones P, Geraghty R, et al. Effect of music on outpatient urological procedures: a systematic review and meta-analysis from the European Association of Urology Section of UroTechnology. J Urol. 2018; 199: 1319-1327.

[31] Bro ML, Jespersen KV, Hansen JB, et al. Kind of blue: a systematic review and meta-analysis of music interventions in cancer treatment. Psychooncology 2018; 27: 386-400.

[32] Sihvonen AJ, Särkämö T, Leo V, et al. Music-based interventions in neurological rehabilitation. Lancet Neurol. 2017; 16: 648660.

[33] Fujioka T, Dawson DR, Wright R, et al. The effects of musicsupported therapy on motor, cognitive, and psychosocial functions in chronic stroke. Ann N Y Acad Sci. 2018; 1423: 264 274 .

[34] Altenmüller E, Schlaug G. Apollo's gift: new aspects of neurologic music therapy. Prog Brain Res. 2015; 217: 237-252.

[35] Landis-Shack N, Heinz AJ, Bonn-Miller MO. Music therapy for posttraumatic stress in adults: a theoretical review. Psychomusicology 2017; 27: 334-342.
[36] Rauscher FH, Shaw GL, Ky KN. Music and spatial task performance. Nature 1993; 365: 611.

[37] Grylls E, Kinsky M, Baggott A, et al. Study of the Mozart effect in children with epileptic electroencephalograms. Seizure 2018; 59: 77-81.

[38] Coppola G, Operto FF, Caprio F, et al. Mozart's music in children with drug-refractory epileptic encephalopathies: comparison of two protocols. Epilepsy Behav. 2018; 78: 100-103.

[39] Xue C, Li T, Yin S, et al. The influence of induced mood on music preference. Cogn Process. 2018; 19: 517-525.

[40] Woloszyn MR, Ewert L. Memory for facial expression is influenced by the background music playing during study. Adv Cogn Psychol. 2012; 8: 226-233.

[41] Castillo-Pérez S, Gómez-Pérez V, Velasco MC, et al. Effects of music therapy on depression compared with psychotherapy. Arts Psychother. 2010; 37: 387-390.

[42] Fancourt D, Perkins R. Effect of singing interventions on symptoms of postnatal depression: three-arm randomised controlled trial. Br J Psychiatry 2018; 212: 119-121.

[43] Leubner D, Hinterberger T. Reviewing the effectiveness of music interventions in treating depression. Front Psychol. 2017; 8: 1109.

[44] Aust S, Filip K, Koelsch S, et al. Music in depression: neural correlates of emotional experience in remitted depression. World $\mathrm{J}$ Psychiatry 2013; 3: 8-17.

[45] Murphy K, Liu WW, Goltz D, et al. Implementation of personalized music listening for assisted living residents with dementia. Geriat Nurs. 2018; 39: 560-565.

[46] van der Steen JT, van Soest-Poortvliet MC, van der Wouden JC, et al. Music-based therapeutic interventions for people with dementia. Cochrane Database Syst Rev. 2017; 5: CD003477.

[47] Janka Z. The impact of mood alterations on creativity. [Hangulatzavarok befolyása a kreativitásra.] Clin Neurosci/Ideggyógy Szle. 2006; 59: 236-240. [Hungarian]

[48] Janka Z. Artistic creativity and bipolar mood disorder. [Múvészi kreativitás és bipoláris kedélyzavar.] Orv Hetil. 2004; 145: 1709-1718. [Hungarian]

[49] Willich SN. Physicians in opera - reflection of medical history and public perception. Br Med J. 2006; 333: 1333-1335.

[50] Winkler G. Doctors, druggists and the ones who seem to be - on the musical stage. [Orvos, patikus és aki annak látszik - a zenés színpadon.] Orv Hetil. 2012; 153: 632-634. [Hungarian]

(Janka Zoltán dr., Szeged, Kálvária sgt. 57., 6725 e-mail: janka.zoltan@med.u-szeged.hu)

\section{„A zene magasabb rendü megnyilatkozás, mint minden bölcsesség és filozófia." (Ludwig van Beethoven)}

A cikk a Creative Commons Attribution 4.0 International License (https://creativecommons.org/licenses/by/4.0/) feltételei szerint publikált Open Access közlemény, melynek szellemében a cikk bármilyen médiumban szabadon felhasználható, megosztható és újraközölhetö, feltéve, hogy az eredeti szerző és a közlés helye, illetve a CC License linkje és az esetlegesen végrehajtott módositások feltüntetésre kerülnek. (SID_1) 